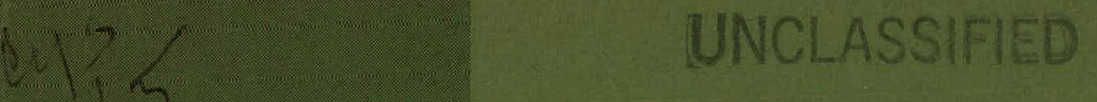

CONFIDENTAL

BNWL-124

\title{
NICKEL ELECTROPLATINC ON URANIUM: SURFACE PREPARATION AND PLATING SOLUTION STUDIES
}

\author{
J. R. LUNDQUIST \\ R. W. STROMATT
}

REPORT

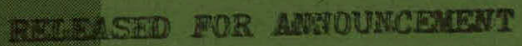

III RUCUEAR SCIDNCE ABSTRACTS
OCTOBER, 1965
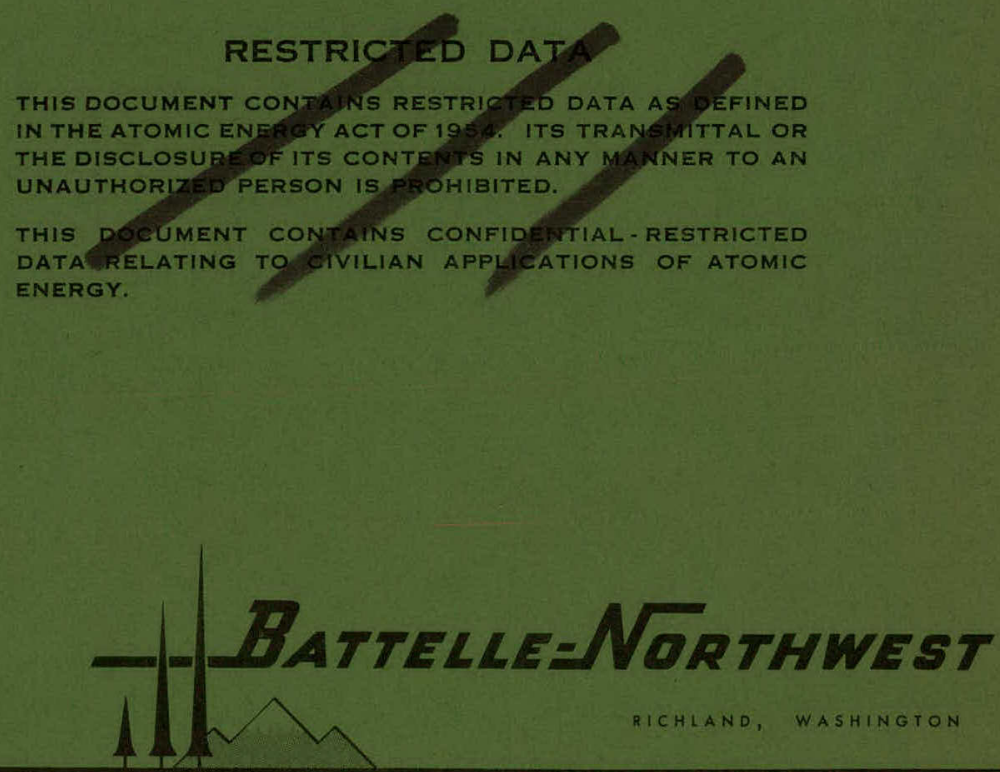

PACIFIC NORTHWEST LABORATORY operated by BATTELLE MEMORIAL INSTITUTE 


\section{DISCLAIMER}

This report was prepared as an account of work sponsored by an agency of the United States Government. Neither the United States Government nor any agency Thereof, nor any of their employees, makes any warranty, express or implied, or assumes any legal liability or responsibility for the accuracy, completeness, or usefulness of any information, apparatus, product, or process disclosed, or represents that its use would not infringe privately owned rights. Reference herein to any specific commercial product, process, or service by trade name, trademark, manufacturer, or otherwise does not necessarily constitute or imply its endorsement, recommendation, or favoring by the United States Government or any agency thereof. The views and opinions of authors expressed herein do not necessarily state or reflect those of the United States Government or any agency thereof. 


\section{DISCLAIMER}

Portions of this document may be illegible in electronic image products. Images are produced from the best available original document. 


\section{LEGAL NOTICE}

This report was prepared us un account of Government sponsored work. Neither the Uniled States, nor the Commission, nor any person acring un Lelialf of the Commissinn.

A. Makes any warranty or representation, expressed or implied, with respect to the accuracy, complcteness, or usefulness of the information contained in this report, or that the use of any information, npparatus, method, or process disclosed in this report may not intringe privately owned rights, or

B. Assumes any liabilities with respect to the use of, or for damages resulliry fiom the usu ul any information, apparatus, method, or process disclosed in this report.

As used in the above, "person acting on behalf of the Commission" includes any employee or contractor of the Commission, or employee of such contractor, to the extent that such employee or contractor of the Commission, or employee of such contractor prepares, disseminates, or provides access to, any information pursuant to his employment or contract with the Commission, or his employment with such contractor.

\section{PACIFIC NORTHWEST LABORATORY}

RICHLAND, WASHINGTON

operated by

BATTELLE MEMORIAL INSTITUTE

for the

UNITED STATES ATOMIC ENERGY COMMISSION UNDER CONTRACT AT(45-1)-1830 


\section{UNCLASSIFIED}

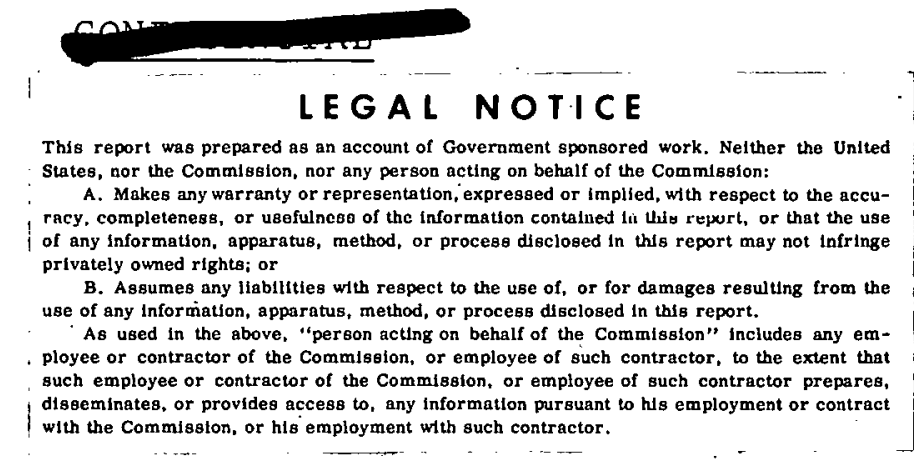

BNWL -124

C-44a, Nuclear Technology-

Materials

(M3679 (4lst Ed.)

NICKEL ELECTROPLATING ON URANIUM:

SURFACE PREPARATION AND PLATING SOLUTION STUDIES

By

J. R. Lundquist and R. W. Stromatt

Chemical Research Section

Chemistry Department

October, 1965

R E S T R P T E D A P

This documot contains Restricted as definean the Atomic Energy Act of Its transmittal the disclosur of its contents in any manner an unthorizedpesion is pronriated.

\section{PACIFIC NORTHWEST LABORATORY \\ RI CHLAND, WASHINGTON}

\section{Group 1}

Excluded from Automatic Downgrading and Declassification

\section{CLASSIFICATION CANCELLED}

DATE

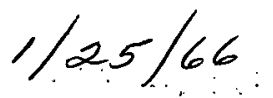

For The Atomic Energy Commission<smiles>[Y]#[V]</smiles><smiles>C=C(CC)OCCCCC</smiles>

Chief, Declassification Branch 


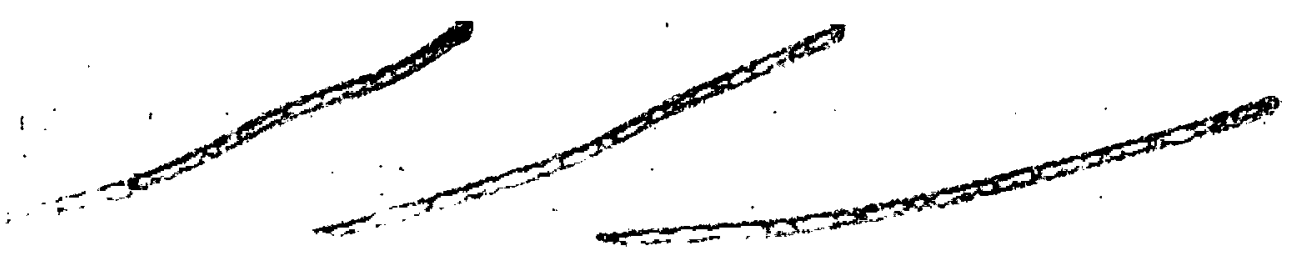

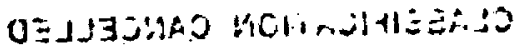

Atidg

Printed in USA. Charge \$.75. Available from the U. S. Atomic

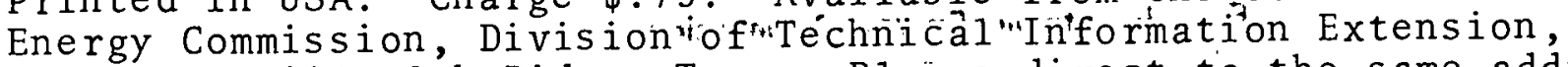
P. 0. Box 1001, Oak Ridge, Tenn. Please direct to the same address inquiries covering the procurement. of other."classified AEC reports. axportons 


\section{UNCLASSIFIED}

\section{TABLE OF CONTENTS}

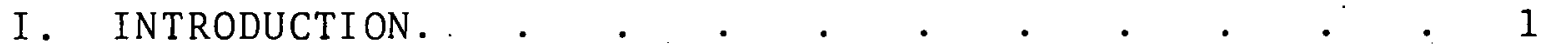

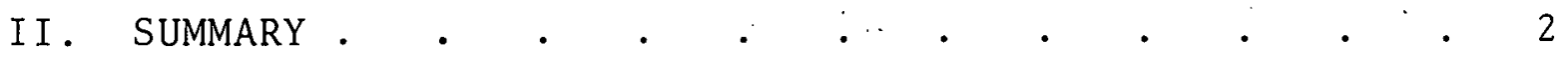

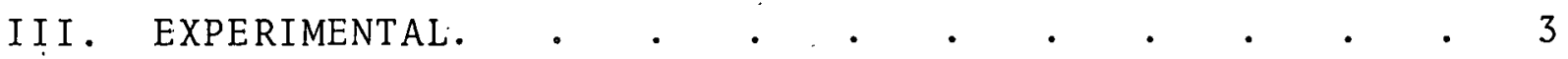

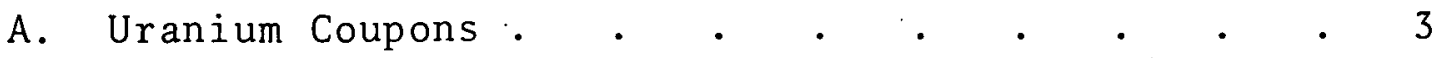

B. Nickel Plating Bath Conditions . . . . . 3

C. Apparatus . . . . . . . . . . 3

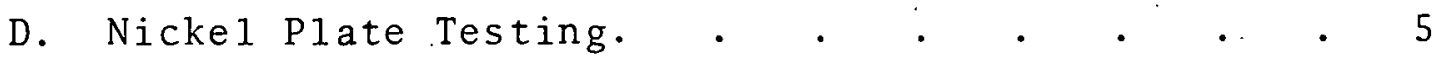

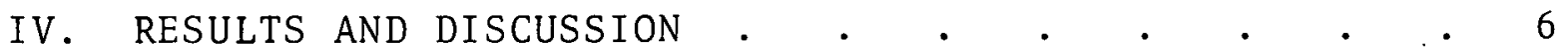

A. Uranium Surface Studies • • • • • • • • •

1. Anodic Etch . . . . . . . . . 7

2. Potential Measurements . . . . . . 13

3. Decomposition Potential Measurements. • . 18

4: Impurity and Grain Size Effects : • : . 19

5. Hot Die Sizing Tests. • • • • • • . 19

B. Nickel Electroplating Studies . . . . • . 20

1. Reactivity Measurements . • . . . . . . 21

2. A. C. Plating . . . . . . . . 22

3. Ultrasonic Agitation. • . . . . . . 23

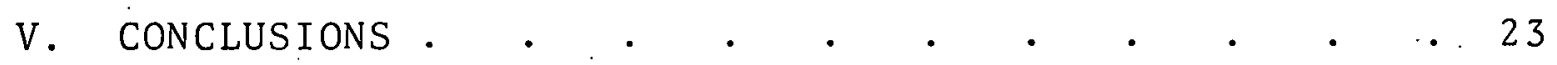

VI. APPENDIX: POROSITY TEST. $. \quad \therefore \quad . \quad . \quad . \quad . \quad . \quad 25$

A. Introduction. . . . . . . . . . . 25

B. Basis . . . . . . . . . . . . 25

C. Procedure $. \quad . \quad . \quad . \quad . \quad . \quad . \quad . \quad . \quad . \quad 26$

D. Validity. • . . . . . . . . . . 26

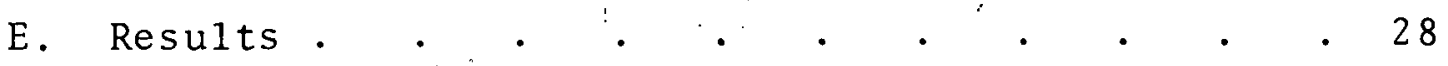


NICKEL ELECTROPLATING ON URANIUM:

SURFACE PREPARATION AND PLATING SOLUTION STUDIES

\section{INTRODUCTION}

The hot die sizing process ${ }^{(1)}$ for cladding uranium metal reactor fuel elements with aluminum requires the use of a thin nickel bonding layer between the uranium and aluminum. The nickel layer acts as a diffusion and secondary corrosion barrier; it prevents the formation of undesirable aluminum-uranium compounds. The uranium-nickel-aluminum bond formed in the cladding operation provides good heat transfer. Some of the necessary characteristics of the nickel layer are that it adhere to the uranium (to allow for the desired heat transfer characteristics), that it be nonporous (to prevent interdiffusion between uranium and aluminum), and that it be free of impurities which might be detrimental to the performance of life of the fuel element. Also it is highiy desirable that the nickel layer be as thin as possible, to keep parasitic neutron capture to a minimum.

An aqueous nickel electroplating process is currently used for application of nickel layer to the uranium. Because certain problems in process control were being encountered in pilot-scale plating operations, and because a plate thickness of 20 to $25 \mu$ was found necessary to assure nonporosity with the process then. in use, a laboratory study of process variables was initiated at Hanford about three'years ago. The objectives of the laboratory program were to develop techniques permitting:

- Improved process control and more efficient operation

- Reduction in nickel coat thickness

- Reduction in the amount of uranium metal removed during the surface cleaning operation 


\section{UNCLASSIFIED}

Early results of this study. were described in 1963, by Braun and Stromatt. (2) when they reported:

- The development of an electrochemical technique to characterize the uranium surface resulting from a given pretreatment and to evaluate various uranium pretreatments

- A comparison of various surface pretreatment-plating bath combinations in térms of the pitting, adherence and porosity of the experimental plates

Later results of the laboratory program (through 1964) are presented in this paper.

\section{I. SUMMARY}

Several advances have been made in the art of nickel. plating uranium electrolytically. As a result, it has been found possible in the laboratory to prepare adherent $11-\mu$ thick plates with porosities equivalent to the porosity of $18-\mu$ plates prepared by the "standard" procedure. The principal improvements are:

- Use of an improved anodic etch solution, $0.32 \mathrm{M} \mathrm{HCl}$ in $6.0 \mathrm{M} \mathrm{H}_{2} \mathrm{SO}_{4}$. This treatment not only provides a uniform, finely etched surface, but does so with the dissolution of less uranium metal than with the $\mathrm{H}_{3} \mathrm{PO}_{4}-\mathrm{HCl}$ anodic etch treatment.

- Substitution of bromide for the chloride normally present in the conventional watts nickel plating bath. The bromide solution is less corrosive, and produces less corrosion product at the uranium-nickel interface.

An $X$-ray fluorescence technique for the determination of relative porosity of nickel. plated uranium specimens was developed. The specimen is briefly anodized in a $\mathrm{K}_{4} \mathrm{Fe}(\mathrm{CN})_{6}-\mathrm{KNO}_{3}$ solution, and the resulting uranyl ferrocyanide precipitate at the pore sites is determined by measurement of the intensity of the $X$-ray fluorescence from the iron component of the precipitate.

\section{UNCLASSIFIED}




\section{UNCLASSIFIED}

III . EXPERIMENTAL

\section{A. Uranium Coupons}

The uranium metal samples used were segments of Hanford 8 in. I \&E fuel elements (ingot metal).

B. Nickel Plating Bath Conditions

Nickel plating bath composition and temperature, and current densities used are listed below:

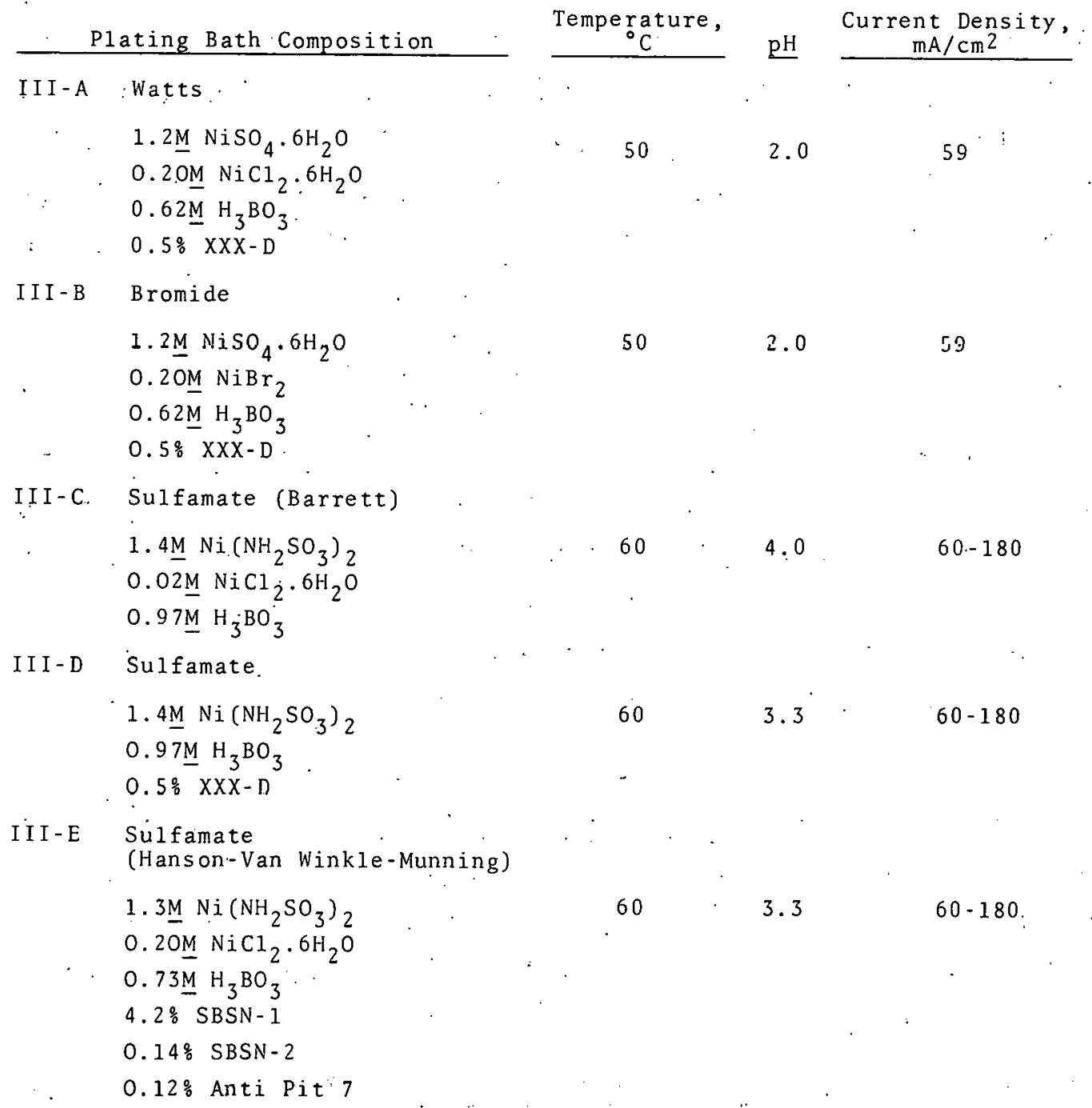




\section{UNCLASSIFIED}

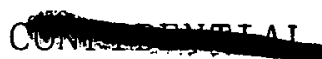

4

$B N W L-124$

\section{Apparatus}

Anodization Studies - The cell for the anodization studies consisted of a uranium anode and two $1 / 4$ in. spectrographic carbon cathodes (one on each side of the anode), mounted in an $85 \mathrm{~mm}$ diam glass container filled with $450 \mathrm{ml}$ of the test solution. The uranium specimen was held between the two platinum contacts in a frame insulated. from the solution with a Unichrome coating. The cell current was monitored by a recording ammeter.

Potential. Measurements - After the desired surface treatment, the uranium specimen was placed in the electrode holder (described above) and suspended in an $85 \mathrm{~mm}$ diam glass cylinder of $450 \mathrm{ml}$, unstirred $0.5 \mathrm{M} \mathrm{NaClO}_{4}$ solution. The potential of the uranium electrode versus a saturated calomel electrode (separatcd from the solution by an unfired Vycor membrane) was mcasurcd with a Sargent Model MR recording potentiometer.

Decomposition Potential Measurements - Thc uranium specimen was clamped at one cnd and immersed in the test solutions in such a way that the clamp did not come in contact with the solution. The counter. electrode was $1 / 4$ in. diam spectrographic graphite rod, and the reference was a saturated calomel electrode separated from the test solution by an unfired Vycor membrane. The uranium electrode potential was varied at a rate of $0.2 \mathrm{~V} / \mathrm{sec}$ using an Anatrol Model 4100 Potentiostat, and the current-potential curves were recorded on an $X-Y$ recorder...

Capacitance Measurements - The single pulse. galvanostatic technique described by Hackermann ( 3 ) was used. The pulse was provided by a Tektronix Type 163 generator, and the resulting data were recorded with a Tektronix $535 \mathrm{~A}$ oscilloscope and a C-3 camera.

Reactivity Measurements - The uranium specimen was placed in the test plating solution, and the spontaneous 


\section{UNCLASSIFIED}

anodic current developed. was followed by recording the IR drop across a $5 \cdot \Omega$ resistor in series with the uranium anode and a graphite cathode.

Electrodeposition of Nickel - The uranium specimen was placed in the electrode holder and suspended in a $114 \mathrm{~mm}$ diam thermostated glass cell containing $820 \mathrm{ml}$ of plating solution. Three nickel anodes in nylon bags were arranged symmetrically around the uranium. Care was taken in the electrode placement to keep the current density uniform over the uranium surface of interest. The agitation of the plating solution was provided by a magnetic stirrer and cell baffles. The plating current was provided by an Electro Products Laboratories Model $\mathrm{N}$ dc power supply. The current was continuously monitored by the recording ammeter.

\section{A. C. Electroplating - The alternating current}

which is superimposed on direct"current, was provided by a Hewlett-Packard Model 204B oscillator and amplified by a Dynaki.t Mark III audio amplifier. The direct current was monitored by the recording ammeter, and the alternating current was monitored by a Weston A. C. Ammeter (frequency response, 25 to $500 \mathrm{cps}$. The more important variable, the alternating to direct voltage ratio, was measured with an oscilloscope.

U1trasonic Agitation - The plating cell was placed in the tank of an Ultrasonic Industries Disontegrator. The generator frequency, was $40 \mathrm{kc} / \mathrm{sec}$ with a power output of $375 \mathrm{~W}$, and three $2 \times 31 / 2$ in. lead zirconate composite transducers were positioned in the bottom of a $14 \times 10 \times 12$ in. tank.

D. Nickel Plate Testing

The adherence was graded by examination of the plate with a sharp knife, while the porosity was graded by examination 


\section{UNCLASSIFIED}

for the formation of blisters and ruptured blisters as described by Braun and Stromatt. (2). A more quantitative porosity test also used is described in the appendix.

IV. RESULTS AND DISCUSSION

\section{A. Uranium Surface Studies}

Uranium metal billets (received from the foundry) must be cleaned before they can be nickel-plated successfully. To obtain a suitable surface, not only must foreign matter and uranium oxides be removed but also some of the work-distorted uranium crystals. Common methods for surface preparation involve chemical, mechanical, or electrolytic etching operations. Some of the techniques described are: $\mathrm{SnCl}_{2}$-ethanol, (4) aqueous $\mathrm{CuCl}_{2}-\mathrm{HF},{ }^{(4)}$ and aqueous $\mathrm{CH}_{3} \mathrm{COOH}-\mathrm{HCl}$ chemical etches; ${ }^{(5)}$ shot blasting mechanical etch; ${ }^{(6)}$ and anodization in the solutions $\mathrm{H}_{3} \mathrm{PO}_{4}-\mathrm{HCl}$, (7) $\mathrm{CCl}_{3} \mathrm{COOH}-\mathrm{HCl},{ }^{(8)} \mathrm{HCl},{ }^{(9)}$ or $\mathrm{llNO}_{3} \cdot(10)$ Most of these etchants require an $\mathrm{INO}_{3}$ pickling step to remove a black reaction product from the uranium surface.

Since the atmospheric and aqueous environments in which the uranium is pretreated and plated react with uranium, it is not possible to prepare a completely oxide-free surface, and a compromise must be reached. For the resulting plate to be satisfactorily adherent and nonporous, the following criteria in the surface preparation must be met:

- The oxide film on the uranium after pretreatment should be uniform to allow a uniform plating current density, should provide some protection from the plating solution, and should not be bulky or passive in nature.

- The surface should have a uniform etch to allow uniform plating current density and provide sufficient "lock and key" adherence, but should not have deep valleys or high peaks which can cause noncontact and thin spots, respectively.

sic respectively.

- 
For economic reasons, the amount of uranium removed during pretreatment should be kept to a:minimum.

\section{Anodic Etch}

In searching for a means to reduce the plate thickness required to assure nonporosity, the anodic etch step of the surface preparation procedure seemed the logical point of attack.

In earlier work in this laboratory, several anodic and chemical etch solutions were tested, but were unsatisfactory in one or more aspects. (2) For the present studies, $\mathrm{HNO}_{3}-\mathrm{HCl}$ and $\mathrm{H}_{2} \mathrm{SO}_{4}-\mathrm{HCl}$ anodic etch solutions were selected for evaluation and comparison with the commonlyused $\mathrm{H}_{3} \mathrm{PO}_{4}-\mathrm{HCl}$. This selection was made for several reasons. First, it was observed that uranium shows the typical current-potential passivation or electropolish relationship upon anodic polarization in $\mathrm{HNO}_{3}$ and $\mathrm{H}_{2} \mathrm{SO}_{4}$, just as it does in $\mathrm{H}_{3} \mathrm{PO}_{4}$ (The uranium surface becomes very shiny and relatively inactive). And second, it has been reported by post and $\operatorname{Kerr}(11)$ that the addition of $\mathrm{HCl}$ to $\mathrm{H}_{3} \mathrm{PO}_{4}$. changes the anodization effect from a polishing to an etching action, the $\mathrm{HCl}$ concentration affecting the coarseness of the etch. Apparent1y the effect of the $\mathrm{HCl}$ is to provide controlled corrosion, counteracting the passivating or polishing effect of the $\mathrm{H}_{3} \mathrm{PO}_{4}$. It was anticipated the same effect would be true for $\mathrm{HNO}_{3}$ and $\mathrm{H}_{2} \mathrm{SO}_{4}$.

In these studies, uranium coupons were anodized in $5.4 \mathrm{M} \mathrm{H}_{3} \mathrm{PO}_{4}-0.26 \underline{\mathrm{M}} \mathrm{HCl}$ and in $\mathrm{HNO}_{3}-\mathrm{HCl}$ and $\mathrm{H}_{2} \mathrm{SO}_{4}-\mathrm{HCl}$ solutions of several different concentrations: Even with very low $\mathrm{HCl}$ concentrations, the $\mathrm{HNO}_{3}-\mathrm{HCl}$ anodization caused severe pitting and was discarded. However, uranium anodized in solutions containing $0.32-0.50 \underline{\mathrm{M} \mathrm{HCl}}$, and $5.5-6.5 \underline{\mathrm{M}} \mathrm{H}_{2} \mathrm{SO}_{4}$ was observed to be uniformly and finely etched, and appeared to have the surface characteristics necessary for the application of a thin, adherent.nickel plate. 
The relative etching effects of $\mathrm{H}_{3} \mathrm{PO}_{4}-\mathrm{HCl}$ and $\mathrm{H}_{2} \mathrm{SO}_{4}-\mathrm{HCl}$ solutions are shown by the photomicrographs in Figure 1. These cross sections of nickel-plated specimens show that the surface roughness is considerably less for the uranium etched in $\mathrm{H}_{2} \mathrm{SO}_{4}-\mathrm{HCl}$ (the peaks and valleys being significantly decreased). However, the surface of uranium anodized in $\mathrm{H}_{2} \mathrm{SO}_{4}-\mathrm{HCl}$ is sufficiently etched to contribute to the mechanical "lock and key" effect necessary for good adherence.

A rough estimate of the difference in roughness (or surface area) was obtained by double layer capacitance measurements, the measured capacity being proportional to the surface area. The double layer capacity for uranium anodized in $5.4 \underline{\mathrm{M} \mathrm{H}}{ }_{3} \mathrm{PO}_{4} \cdots 0.26 \underline{\mathrm{M}} \mathrm{HCl}$ was $57 \mu \mathrm{F} / \mathrm{cm}^{2}$ and in $6.0 \mathrm{M}_{2} \mathrm{H}_{4} \mathrm{SO}_{4}$ $0.32 \mathrm{M} \mathrm{HCl}, 48 \mu \mathrm{F} / \mathrm{cm}^{2}$. This represents a decrease of about $20 \%$. This order of magnitude for the capacitance values indicates that it is indeed the double layer capacity that is measured, not the capacitance of the oxide film, although Figure 1 does show a thicker film on the surface of the uranium anodized in the $\mathrm{H}_{3} \mathrm{PO}_{4}-\mathrm{HCl}$ solution. Both oxide films are probably porous, as shown from the surface activity of the uranium (see potential measurements section) and the capacitance measurements.

Unplated, or thinly covered peaks on the uranium surface are only one of the sources of pores and thin areas in the nickel plate. The cross-sections in Figure 1 and the electron micrographs in Figure 2 show pores extending from the nickel surface out through the nickel plate, apparently originating from areas on the uranium surface on which the nickel did not nucleate. The cause is not readily apparent. It may be that some uranium crystals are oriented in such a way as to present a face to the surface which is readily passivated, or on which there is a large nickel overvoltage. These àreas are eventually covered as the nickel plate thickness increases and the nickel bridges over the pores. 

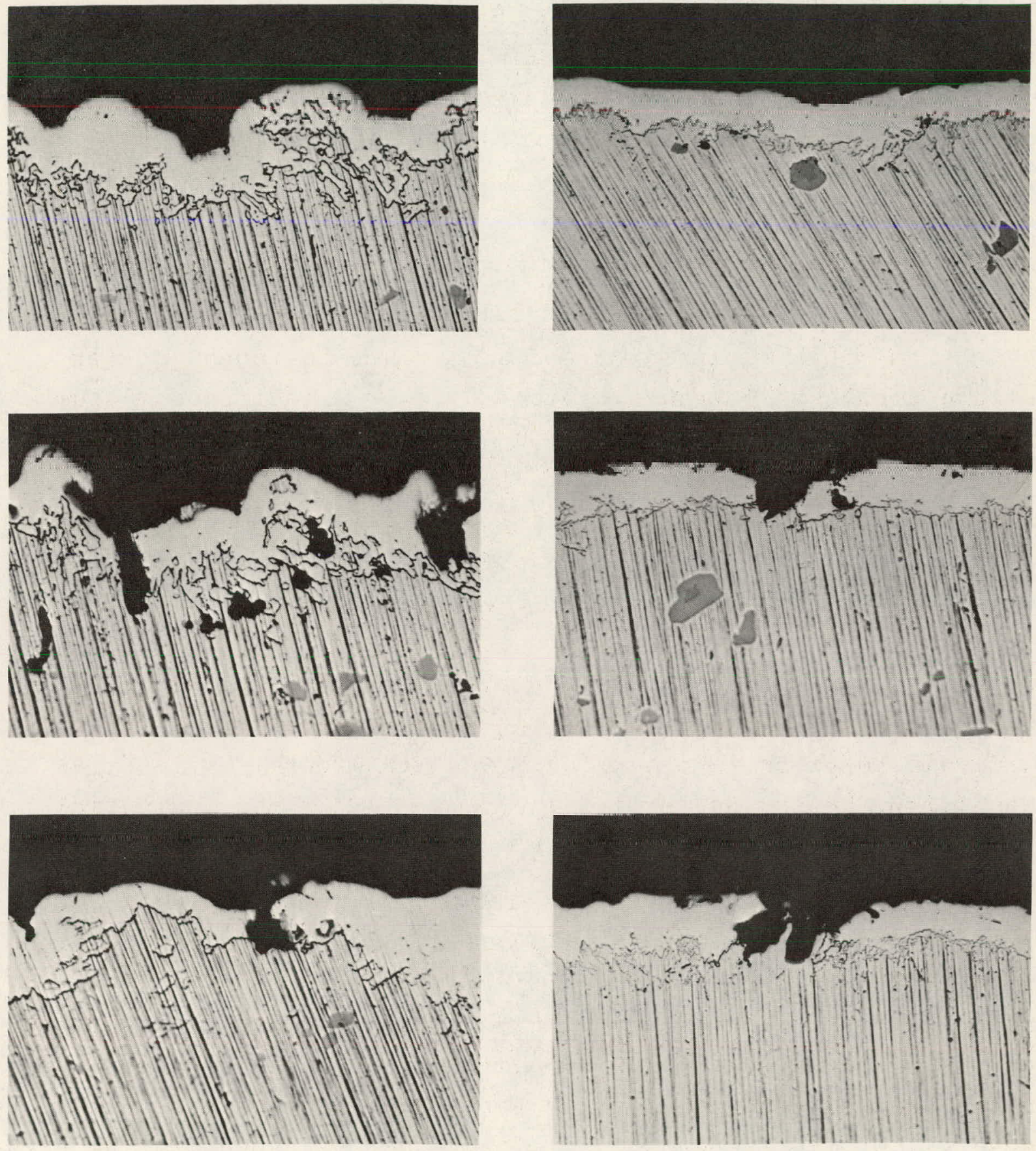

$$
\mathrm{H}_{3} \mathrm{PO}_{4}-\mathrm{HCl} \text { Anodic Etch }
$$$$
\mathrm{H}_{2} \mathrm{SO}_{4}-\mathrm{HCl} \text { Anodic Etch }
$$

$$
\text { Cross Sections of Nickel Plated Uranium }
$$

Neg. 0651771- 1 


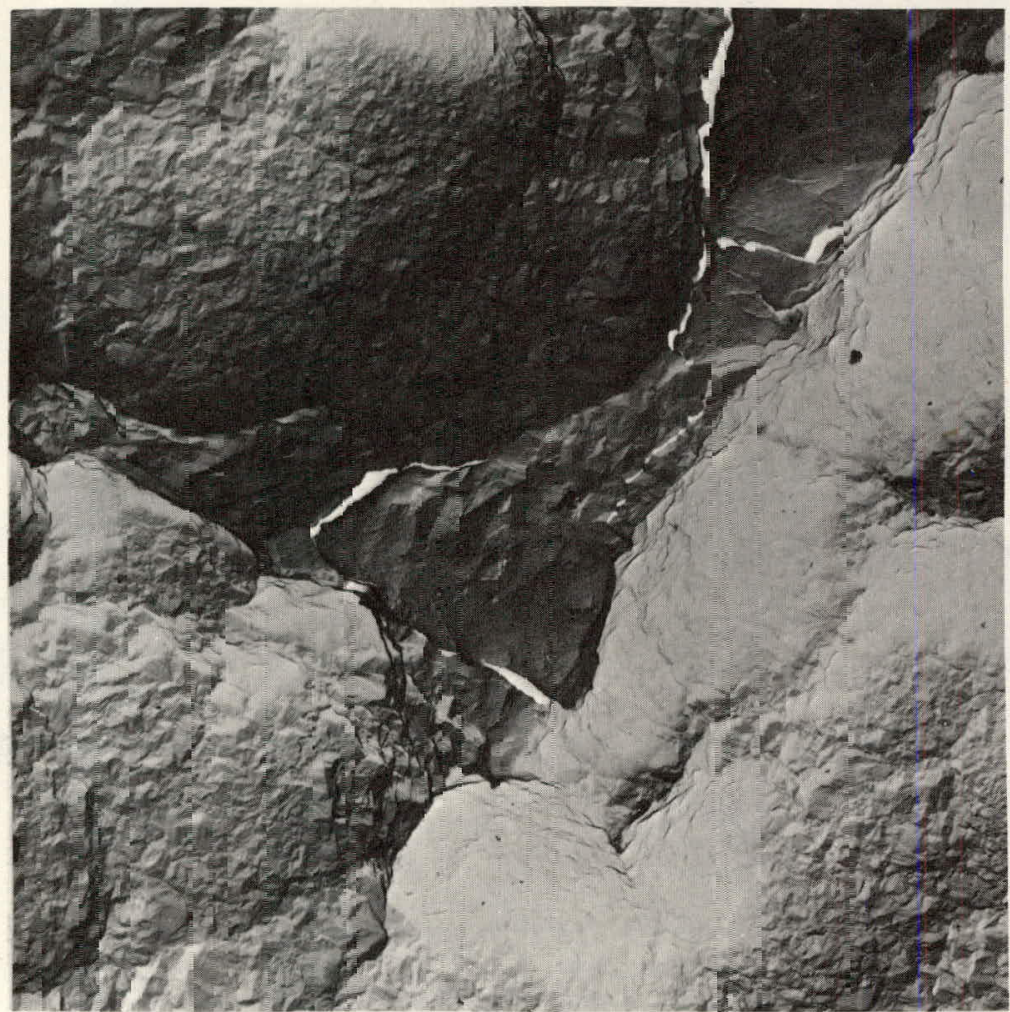

Large Area of Exposed Uraniun

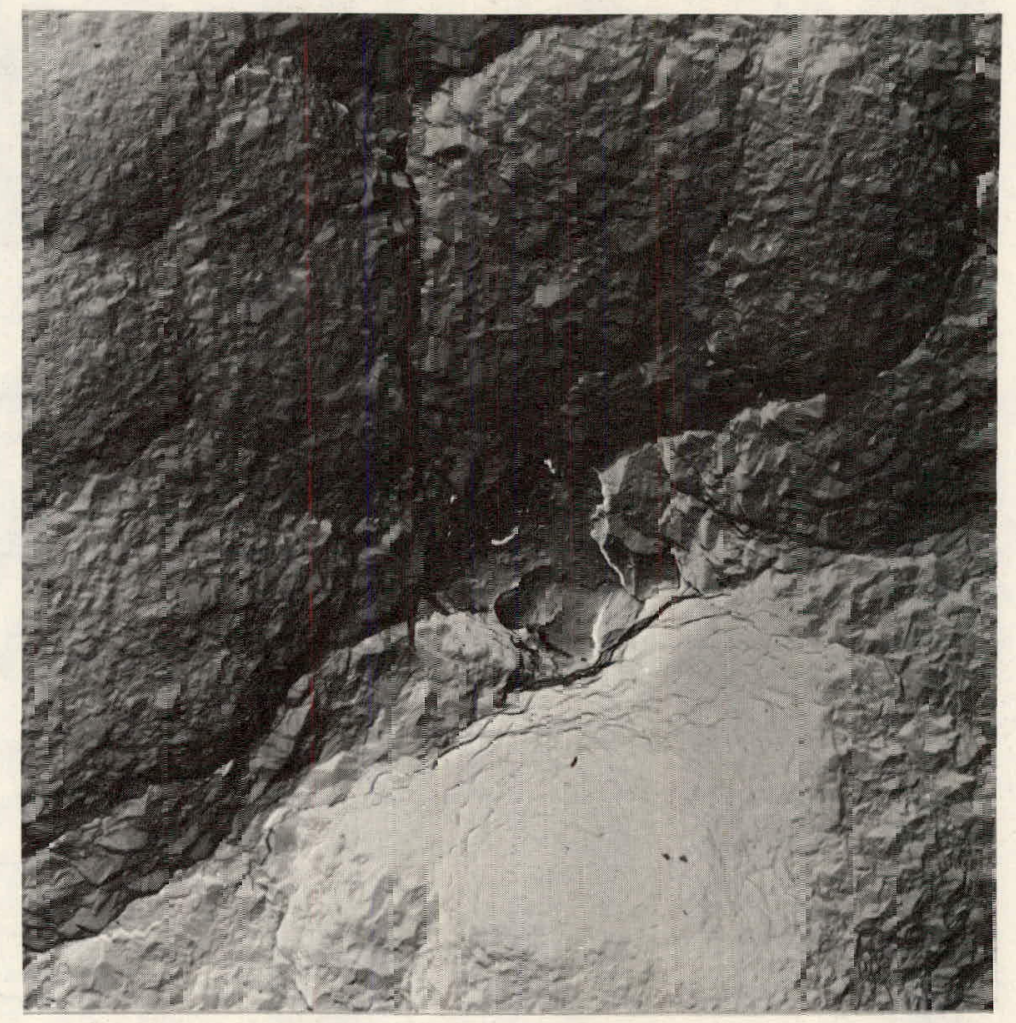

Sma11 Area of Exposed Uranium

FIGURE 2

Electron Micrographs of Nickel Electrodeposited on Uranium $3000 x$

Neg. 0651771-2 


\section{UNCLASSIFIED}

The preferred procedure for the preparation of uranium surfaces using the $\mathrm{H}_{2} \mathrm{SO}_{4}$ - $\mathrm{HCl}$ anodic etch solution is shown in Table I. For the anodization step itself, a range of possible conditions is given. The optimum has been found to be (on a laboratory scale): anodization at a current density of $59 \mathrm{~mA} / \mathrm{cm}^{2}$ for $4 \mathrm{~min}$, in $6.0 \mathrm{M} \mathrm{H}_{2} \mathrm{SO}_{4}-0.32 \mathrm{M} \mathrm{HCl}$ at room temperature.

\section{TABI,F. T}

\section{OUTLINE OF $\mathrm{H}_{2} \mathrm{SO}_{4}-\mathrm{HCl}_{\text {ANODIC ETCH PROCEDURE }}$}

\begin{tabular}{|c|c|c|c|c|}
\hline Step & Solution & $\begin{array}{c}\text { Temperature } \\
{ }^{\mathrm{C}} \\
\end{array}$ & $\begin{array}{c}\text { Time } \\
\text { Minutes }\end{array}$ & $\begin{array}{r}\text { Current } \\
\text { Density } \\
\mathrm{mA} / \mathrm{cm}^{2} \\
\end{array}$ \\
\hline Degrease & Ace tone & Ambient & 1 & -- \\
\hline Degrease & $0.1 \%$ Duponal in $2 \underline{\mathrm{M}} \mathrm{NaOH}$ & 85 & 2 & -- \\
\hline Rinse & Demineralized Water (dip) & Ambient & $1 / 6$ & --- \\
\hline Pickle & $10 \underline{\mathrm{M}} \mathrm{HNO}_{3}$ & 65 & 1 & $-\cdot$ \\
\hline Rinse & Demineralized Water (running) & Ambient & $1 / 6$ & -- \\
\hline Anodization & $6.0 \mathrm{M} \mathrm{H}_{2} \mathrm{SO}_{1}-0.32 \mathrm{M} \mathrm{HCl}$ & 25 to 50 & 3 to 10 & 30 to 90 \\
\hline Rinse & Demineralized Water (running) & Ambient & $1 / 6$ & -- \\
\hline Pickle & $8 \underline{\mathrm{M}} \mathrm{HNO}_{3}$ & 40 & 1 to 5 & -- \\
\hline Rinse & Demineralized Water (running) & Ambient & $1 / 6$ & -- \\
\hline
\end{tabular}

Uranium pieces were prepared by both methods (the $\mathrm{H}_{3} \mathrm{PO}_{4}-\mathrm{HCl}$ etch and the $\mathrm{H}_{2} \mathrm{SO}_{4}-\mathrm{HCl}$ etch), and were plated in Watts, Barrett Sulfamate, and Hanson-Van Winkle-Munning Sulfamate solutions. These plates were tested for porosity and adherence by the $\mathrm{X}$-ray technique described in the appendix and by subjecting them to a $5 \mathrm{~min}, 600^{\circ} \mathrm{C}$ heat treatment in air followed by air cooling. Adherence and porosity of these samples were significantly improved over samples prepared by the usual techniques. For example, an $11 \mu$ nickel plate on samples anodized in the $\mathrm{H}_{2} \mathrm{SO}_{4}-\mathrm{HCl}$ solution was equivalent in terms of adherence and porosity to $18 \mu$ nickel coats on samples prepared by anodization in the $\mathrm{H}_{3} \mathrm{PO}_{4}-\mathrm{HCl}$ solution. For plates of equal thickness, the number of pores is decreased by a factor of about eight using the $\mathrm{H}_{2} \mathrm{SO}_{4}-\mathrm{HCl}$ solution rather than $\mathrm{H}_{3} \mathrm{PO}_{4}-\mathrm{HCl}$ (Figure 3). 


\section{UNCLASSIFIED}

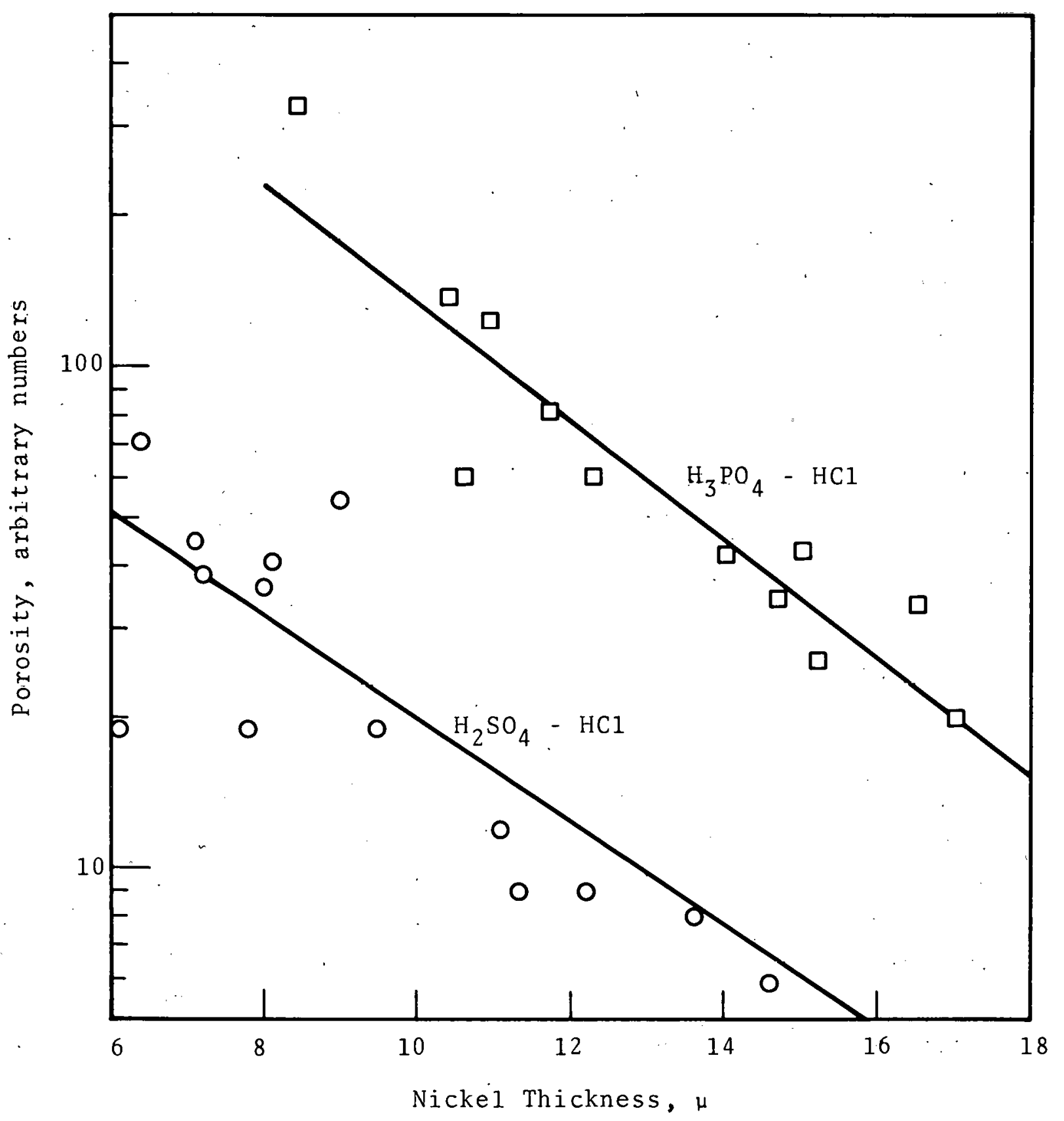

FIGURE 3
Porosity of Nickel Plated Uranium
as a Function of Plate Thickness

$\mathrm{C} \longrightarrow \mathrm{L}$ 


\section{UNCLASSIFIED}

There are three additional advantages to using the $\mathrm{H}_{2} \mathrm{SO}_{4}-\mathrm{HCl}$ anodic etch solution. The first is a $60 \%$ decrease in uranium removal without sacrifice of plate quality. Satisfactory results were obtained after removing $14 \mathrm{mg} / \mathrm{cm}^{2}$, while removal of 30 to $150 \mathrm{mg} / \mathrm{cm}^{2}$ is needed with various other etching techniques. The second advantage is that the uranium product from the anodization is neither very soluble in $\mathrm{H}_{2} \mathrm{SO}_{4}-\mathrm{HCl}$ at room temperature, nor is it gelatinous, as is the uranium product from the $\mathrm{H}_{3} \mathrm{PO}_{4}-\mathrm{HCl}$ anodization. Hence, removal of the anodization product from the solution is reasonably easy. The third advantage is that $\mathrm{H}_{2} \mathrm{SO}_{4}$ is cheaper than $\mathrm{H}_{3} \mathrm{PO}_{4}$.

\section{Potential Measurements}

As mentioned earlier, the surface treatment that is used quite extensively for conditioning uranium before nickel electrodeposition consists essentially of four steps: degrease, pickle in $\mathrm{HNO}_{3}$, anodic etch, and pickle in $\mathrm{HNO}_{3}$. The purpose of the final $\mathrm{HNO}_{3}$ pickle is to remove the nonmetallic film from the uniformly etched and activated surface. During these studies, it" was necessary that variations in pretreatment conditions, and especially variations in the exposure time, solution temperatures, and acid concentration in the final $\mathrm{HNO}_{3}$ pickle step be evaluated. This evaluation was accomplished by taking the uranium specimen through the surface treatment procedure. A measure of the surface activity or passivity is obtained through determination of the "initiàl emf". assumed by the specimen (versus a saturated calomel electrode) when immersed in a $\mathrm{NaClO}_{4}$ solution (see "Potential Measurements" in the "Experimental". section). (2) The results of studies of the effect of time and temperature for the final $\mathrm{HNO}_{3}$ pickle step, following anodization in $\mathrm{H}_{2} \mathrm{SO}_{4}-\mathrm{HCl}$, are shown in Figures 4 and 5 . In Figure 4 , the initial emf was plotted versus time in $8 \mathrm{M} \mathrm{HNO}_{3}$, at $40^{\circ} \mathrm{C}$. As shown by the break in the curve, 
UNCLASSIFIED

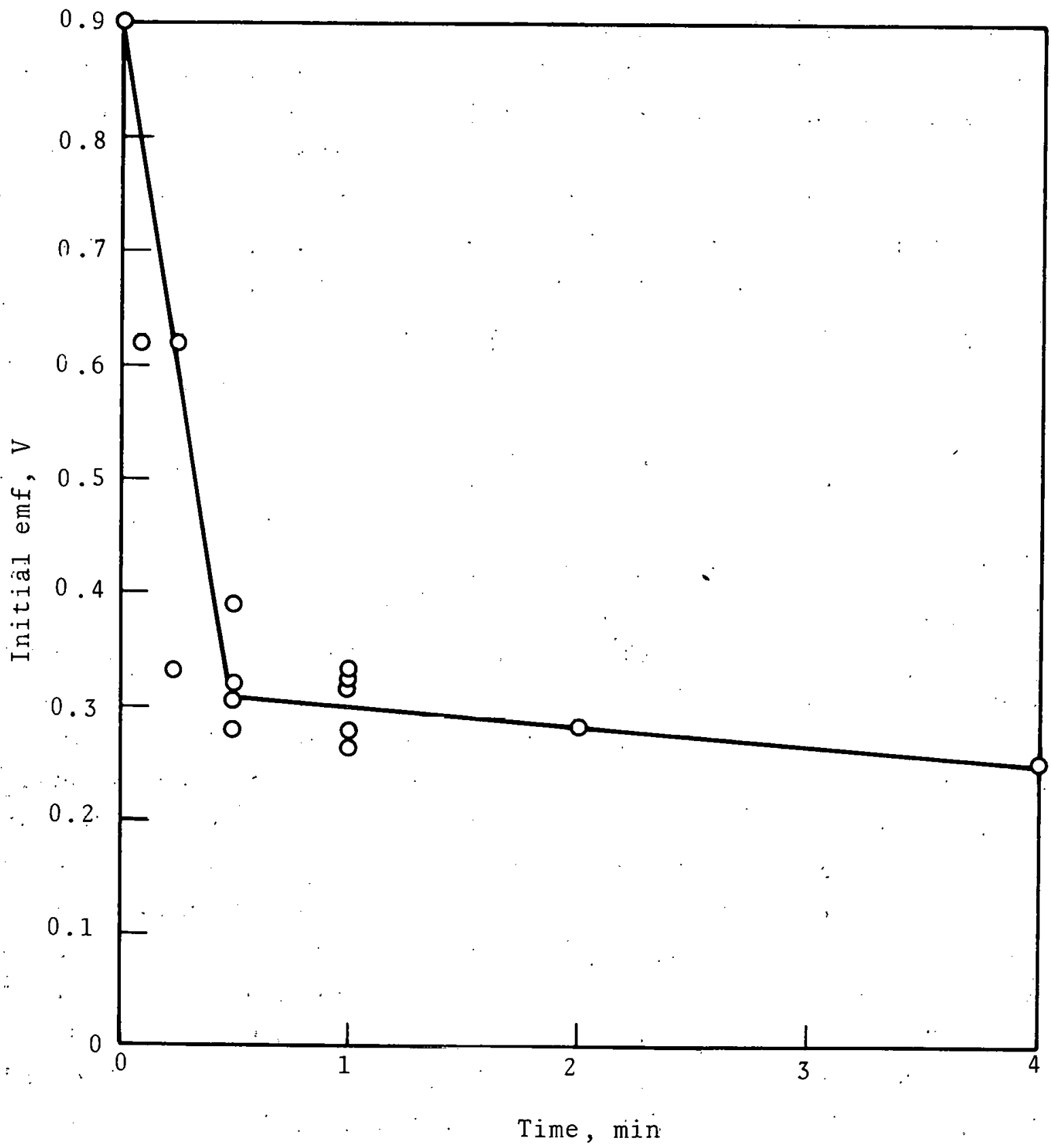

FIGURE 4

Initial Potential of Uranium in Test Solution

As a Function of Time in Final $\mathrm{HNO}_{3}$ Pickle 


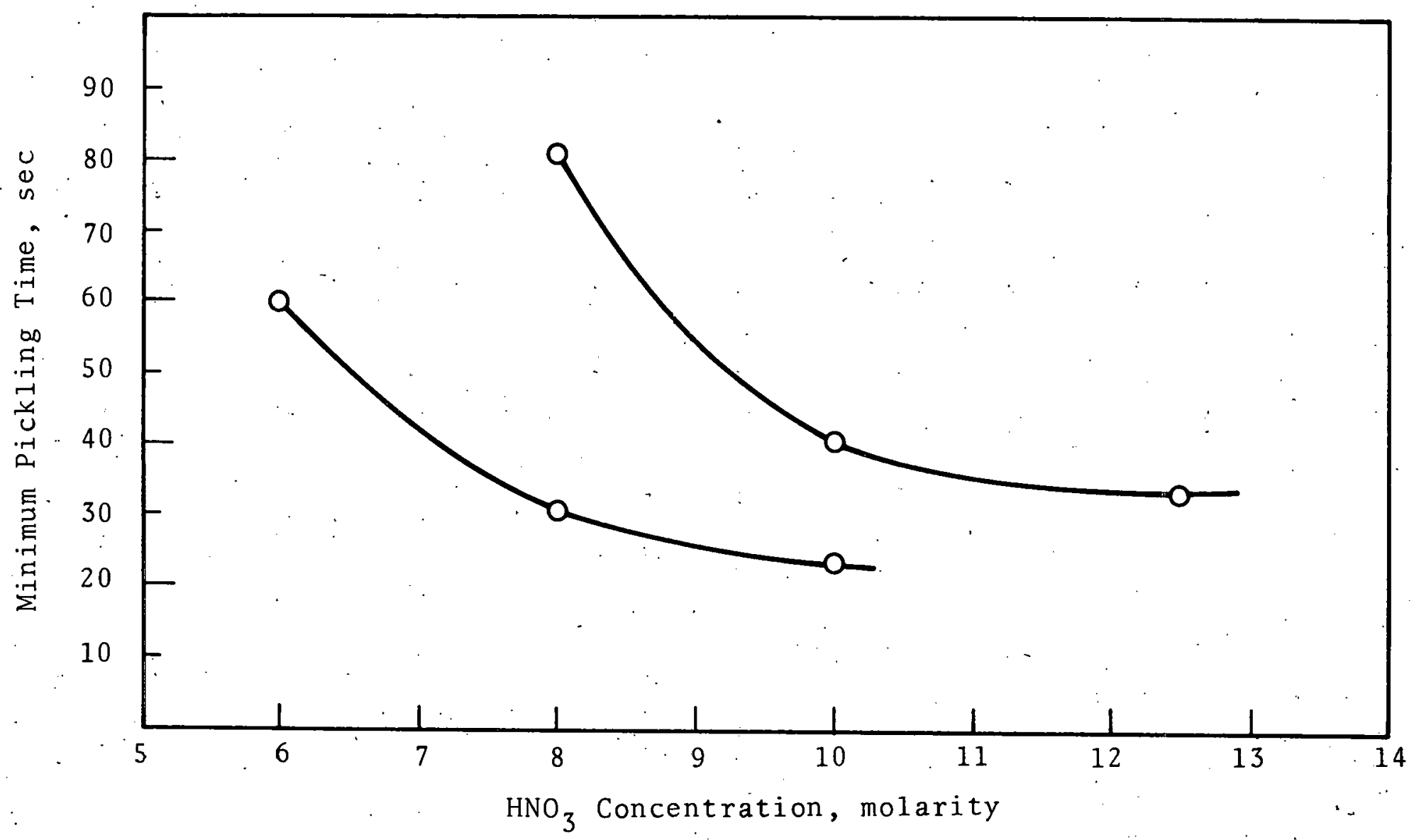

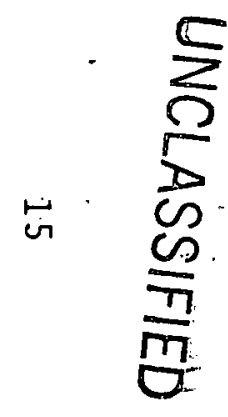

FIGURE 5

Time, Temp., and Concentration Rètionship of Final $\mathrm{HNO}_{3}$. Pickle 


\section{UNCLASSIFIED}

the minimum required-pickling time is $30 \mathrm{sec}$, at which time most of the active anodic film is removed and a more passive film begins to form on the uranium surface. Figure 5 shows the minimum pickling time plotted versus the concentration of $\mathrm{HNO}_{3}$ in the final pickle solution at two temperatures, $25{ }^{\circ} \mathrm{C}$ and $40{ }^{\circ} \mathrm{C}$.

It is apparent that in the surface preparation operation, the final condition of the surface may well depend upon any changes occurring during the transfers of the metal from one process step to another when the surface is exposed to air. The transfer which is of particular importance in this regard is the one occurring between the final $\mathrm{HNO}_{3}$ pickle and the water rinse prior to plating. To investigate the effect of this, air exposure upon the metal surface activity, uranium coupons were anodized for 6 min in $\mathrm{H}_{3} \mathrm{PO}_{4}-\mathrm{HCl}$, pickled for 5 min in $8 \mathrm{M} \mathrm{HNO}_{3}$ at $40{ }^{\circ} \mathrm{C}$, and rinsed in water after various periods of exposure to air following the pickle treatment.

The results (Figure 6 - Curve A) show that the surface becomes less active with increasing air exposure time. These results may be compared with those attained by maintaining a constant air exposure time, but changing the $\mathrm{HNO}_{3}$ pickle time (Figure 6-Curve B). Here also, the surface becomes less active with increased time, although the passivation rate is lower than with air exposure. Previous studies (2) of continuing the $\mathrm{HNO}_{3}$ pickle treatment past the optimum time have shown that the resulting surface passivation has had a detrimental effect upon subsequent nickel plating. Although the nature of the surface resulting from over-pickling may not be the same as that from excessive air oxidation, it is felt that the effect upon nickel plating will be about the same. Therefore it is believed that the air exposure time following the surface preparation should be kept to a minimum.: 


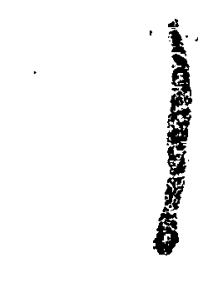

$\frac{5}{2}$
$\frac{5}{0}$
$\frac{N}{\pi}$
$\frac{\pi}{0}$

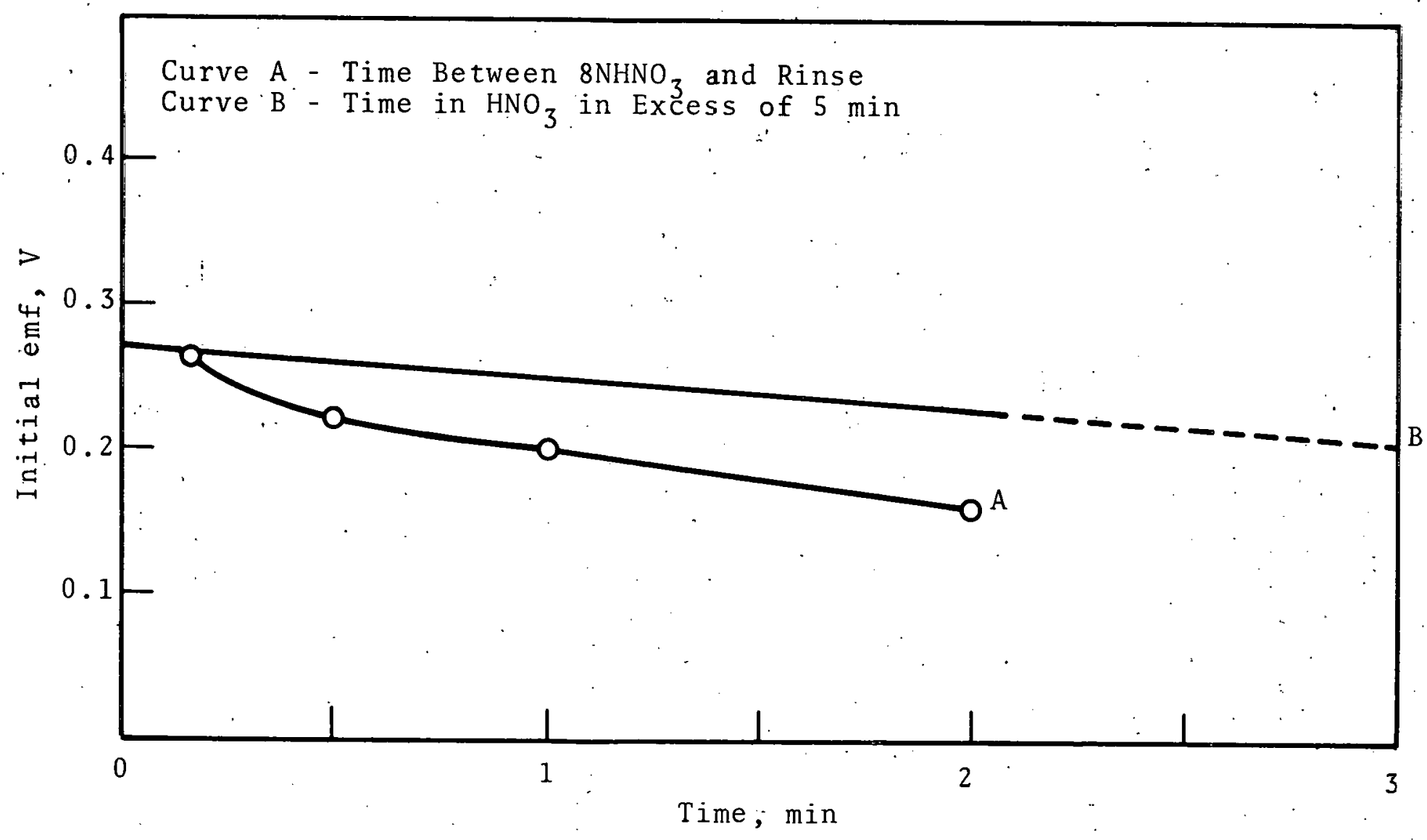

FIGURE 6

Uranium Passivation Rate in Air and Nitric Acid 


\section{UNCLASSIFIED}

\section{Decomposition Potential Measurements}

Polarization curves were run on uranium cathodes previously anodized in $\mathrm{H}_{3} \mathrm{PO}_{4}-\mathrm{HCl}$ or $\mathrm{H}_{2} \mathrm{SO}_{4}-\mathrm{HCl}$, to estimate differences in nickel and hydrogen decomposition potentials on uranium surfaces prepared by the two different procedures. Nickel decomposition potentials were determined in three different plating solutions: Watts (III-A); Bromide (III-B); and Sulfamate (III-C). The electrolyte used in estimating the hydrogen decomposition potential was $1.2 \mathrm{M} \mathrm{Na}_{2} \mathrm{SO}_{4}, 0.4 \mathrm{M} \mathrm{NaCl}, 0.62 \mathrm{M} \mathrm{II}_{3} \mathrm{BO}_{3}$, at a $\mathrm{pH}$ of 2.0 and a temperature of $50^{\circ} \mathrm{C}$.

The hydrogen decomposition potential was the same for both anodic etches $(-1.66 \mathrm{~V})$ and was significantly more negative than for nickel ( $c a-1.2 \mathrm{~V}$ ) on the uranium cathode. Differences were noted in the nickel decomposition potentials for different surface preparations, and this potential became more positive as a uranium specimen corroded in the various plating solutions. As noted in Table II the differences between the nickel decomposition potentials measured for the two types of surface preparation decrease in the plating solutions in the order: Watts > Bromide > Sulfamate. There is less difference in the nickel decomposition potentials with the three plating solutions after the $\mathrm{H}_{2} \mathrm{SO}_{4}-\mathrm{HCl}$ anodization, which is indicative of a more protective anodic film on the uranium from this solution.

TABLE I I

NICKEL DECOMPOSITION VOLTAGE ON URANIUM

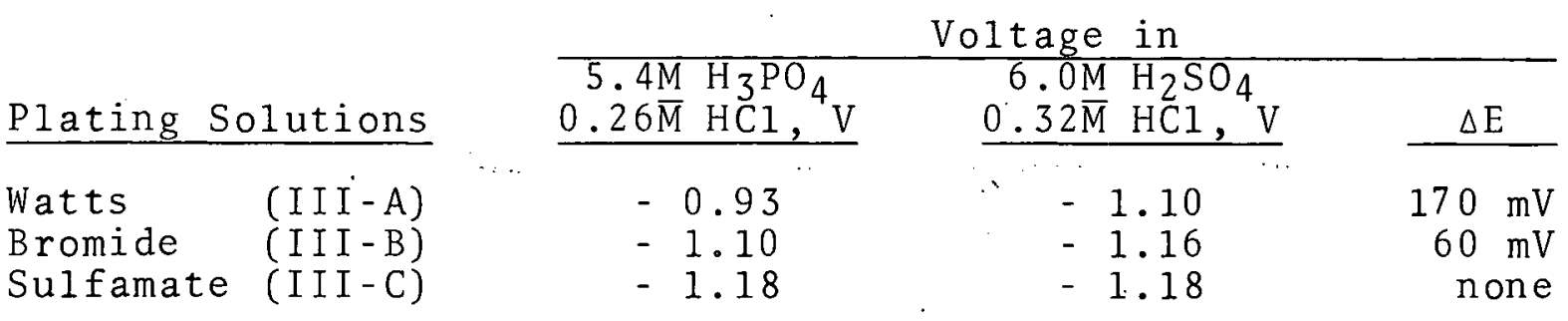




\section{UNCLASSIFIED}

\section{Impurity and Grain Size Effects}

A systematic study was undertaken in search of a correlation between emf measurements and uranium grain size and impurity content. The electrode potential (versus a calomel reference), assumed by a variety of uranium specimens in $\mathrm{NaClO}_{4}$ solutions, was recorded as a function of time. The characteristics of the resulting curves were then related to the uranium properties of interest. The initial emf measurement was found sensitive to carbon content (about $4 \mathrm{ppm} / \mathrm{mV}$ ); the more active potentials reflected a smaller carbon content. The measurements were not sensitive to iron, aluminum, silicon or hydrogen in the metal. The slopes of the recorded emf-time curves at 6 and $12 \mathrm{sec}$ were only slightly sensitive to grain size differences. Since individual variations were quite large, the existence of trends could be shown only by averaging the results from a number of samples. For example, at 6 sec the slope of the curve for untransformed uranium was $-0.89 \pm 0.31 \mathrm{~V} / \mathrm{min}$; the slope for grain sizes 2.94 to 4.29 (minimum voltage UT-2 test) ${ }^{(12)}$ was $-0.68 \pm 0.12 \mathrm{~V} / \mathrm{min}$. Therefore, it appears that the only practical application of this technique for quality control may be for the estimation of carbon content.

5. Hot Die Sizing Tests

A preliminary evaluation was made of the effect of the $\mathrm{H}_{2} \mathrm{SO}_{4}-\mathrm{HCl}$ anodic etch pretreatment upon the behavior of the nickel cladding in hot die sizing operation. Three test cylinders were prepared as follows:

1. Cylindrical sections of standard-quality ingot uranium, $\mathrm{ca} 11 / 2 \mathrm{in}$. long, were pretreated with either the standard $\mathrm{H}_{3} \mathrm{PO}_{4}$ - $\mathrm{HCl}$ anodic etch procedure or the $\mathrm{H}_{2} \mathrm{SO}_{4}-\mathrm{HCl}$ anodic etch test procedure.

2. The sections were piated with nickei, an $18 \mu$ coat being applied to the standard specimens and a $9-13 \mu$ coat being put on the test specimens. 


\section{UNCLASSIFIED.}

3. Cylindrical assemblies, approximating the geometry of a standard HDS fuel element, were then prepared, each cylinder containing three standard segments and two test segments.

4. Each assembly was clad with an 8001 alloy aluminum cap and can using the hot die sizing technique.

For evaluation, four $3 / 16^{\circ}$ in. diameter studs were pulled from each $11 / 2$ in. long segment. The bond strengths for test and standard material were found to be about the same (as shown by the following data).

(Values are pounds of force required to pull a $3 / 16$ in. diam stud.)

\begin{tabular}{|c|c|c|c|}
\hline & Minimum & Maximum & Average \\
\hline Standard & 330 & 780 & 560 \\
\hline Test & 220 & 960 & 590 \\
\hline
\end{tabular}

Forty per cent of the test material studs showed evidence of fracture at the $\mathrm{Ni}-\mathrm{U}$ interface, compared to $6 \%$ for the standard material. Under production conditions, 15 to $30 \%$ of the studs fracture at the U-Ni interface. For the limited number of experiments run, the tests show equivalent results, especially when the poor electrode geometry involved in these experiments is considered. The electroplating of significantly larger pieces (above normal for this equipment) resulted in a decrease in the plate thickness up to $30 \%$ in one shielded area on the uranium.

\section{B. Nickel Electroplating Studies}

The nickel plating studies have involved the evaluation of different plating solutions and the utilization of techniques designed to improve the deposition process. Perhaps the feature most desired in a nickel plating solution for plating uranium, or any active metal, is a low corrosion rate toward that metal. This was the prime criterion in the evaluation of plating solutions. Improvements in the plate itseif were also sought by improvement in the deposition process by ac plating and ultra- 


\section{UNCLASSIFIED}

sonic agitation. Plating solutions evaluated in this and in our prior work were chosen mainly from commercial or well-known sources, and most of their plating properties were excellent. Thus criteria such as throwing power, plate strain, etc. were not of immediate concern.

\section{Reactivity Measurements}

A major problem in plating an active metal (such as uranium in an aqueous solution is that the solution is corrosive to the metal surface (to an extent determined by the composition of the solution) and the temperature. It is important, therefore, that this corrosion effect be kept to a minimum by. using a plating solution that shows minimal reactivity toward the metal. Unfortunately, the chloride ion that is normally added to assure high anode current efficiency in plating uranium does so by increasing the reactivity of the solution, hence increasing the extent of the uranium corrosion.

The relative reactivities of various plating solutions were determined by measuring the spontaneous current flowing through a circuit consisting of a uranium anode and a graphite cathode both immersed in the solutions and connected by a $5 \Omega$ resistor. The results, as given in Table. III, show a significantly lower reactivity when bromide ion is used rather than chloride ion. In both cases, the anode efficiency was $100 \%$.

\section{TABLE III}

\section{REACIIIVITY OF PLATING SOLUTIONS TOWARD URANIUM}

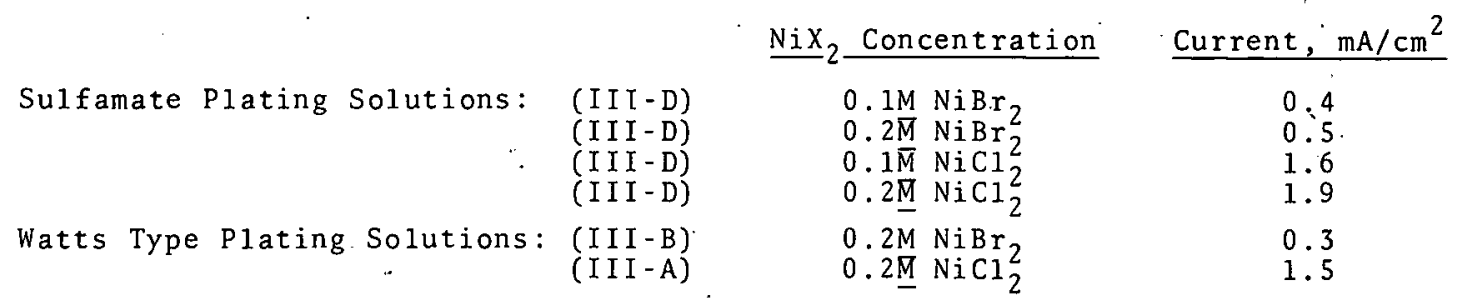

Another indication of relative reactivity of the plating solutions is seen in Table II. The differences in the decomposi- 


\section{UNCLASSIFIED}

tion voltages $(\Delta E)$ of nickel on uranium pretreated by two techniques from the three plating solutions demonstrate that plating solutions react with the anodic film and the uranium with rates decreasing in the order watts > Bromide > Sulfamate. There may be some differences in the decomposition potentials because of the relative thermodynamic stabilities of nickel complexes in these solutions but $\Delta \mathrm{E}$ in this case should be constant.

The best test of the plating solutions is, of course, the quality of the plates they produce on the uranium. Nickel plated uranium specimens were tested for plate porosity by the $\mathrm{X}$-ray technique and for plate integrity by heating them at $600{ }^{\circ} \mathrm{C}$ in air for $5 \mathrm{~min}$, followed by air cooling. These tests demonstrated that the number of pores could be decreased by an approximate. factor of three without loss of plate integrity by substituting bromide for chloride in the Watts plating solution. This allowed a decrease in plate thickness from 17 to $14 \mu$ with no loss in protection. The sulfamate plating solutions normally contain a small amount of chloride (ca $0.05 \mathrm{M}$ ) to promote anode etticiency, but at this low concentration the presence of chloride is apparently not deleterious. Also, the nickel plates on uranium appear to be comparable to the plates from the bromide solution in terms of porosity and integrity.

\section{A. C. P1ating}

Reportedly, alternating current superimposed on direct current can decrease the porosity of electroplated nickel. To test this, uranium was nickel plated under the following conditions:

- Frequency range from 10 to $500 \mathrm{cps}$

- $V_{a c} / V_{d c}$ (ac voltage being $1 / 2$ peak to peak) from 0.7 to 5

- Direct current densities from $20 \mathrm{~mA} / \mathrm{cm}^{2}$ to $55 \mathrm{~mA} / \mathrm{cm}^{2}$

There was no significant improvement in plates obtained under these conditions from either a Watts solution or a Barrett 


\section{UNCLASSIFIED}

Sulfamate solution. This is probably explained as follows. The $\mathrm{V}_{\mathrm{ac}} / \mathrm{V}_{\mathrm{dc}}$ ratios less than unity do not result in any anodization which is required for plate improvement. For ratios greater than unity, the uranium which contacts the solution through pores in the plate is anodized, and no improvement in the plate can result.

3. Ultrasonic Agitation

In experiments with high initial current strikes ( 240


in piate porosity was occasionally obtained. The pH of the solution at the electrode interface increases rapidly under these conditions and $\mathrm{Ni}(\mathrm{OH})_{2}$. precipitates. The resulting nickel plate is very poor. Theoretically, ultrasonic agitation of the proper frequency should decrease the diffusion layer thickness at the electrode," thus maintaining a low $\mathrm{pH}$ and preventing the $\mathrm{Ni}(\mathrm{OH})_{2}$ precipitate even at the high current density. In addition, the extent of adsorption of molecular hydrogen should be decreased, therefore decreasing the need for a wetting agent. The high current density is especially important in decreasing pore density since enough energy (in. terms of electrode potential) is provided for crystal nucleation even at inactive substrate sites.

Forty kilocycles per second ultrasonic agitation was applied to a plating solution, but did not improve the plate. The hydrogen remained adsorbed on the electrode unless the wetting agent was added. The wetting agent caused trouble, "since it appeared to contaminate the plate worse than normal. Recently it has been reported that at $20 \mathrm{kc}$ and a higher power output, an improved nickel plate may be obtained. (14). A systematic study of ultrasonic agitation could prove valuable.

V. CONCLUSIONS

The improvements in the anodic etch and electroplating solutions have resulted in nickel plates on uranium that are 


\section{UNCLASSIFIED}

thinner than those plated via the current "Hot Die Sizing" plating process, and there is no apparent loss in protection for the uranium. Also, the amount of uranium removed in the surface preparation steps is reduced. The actual savings due to the improved neutron economy in the reactors, lower uranium loss, and lower chemical costs in the surface preparation steps, cannot be determined until this proposed procedure is tested on a pilot plant scale (scale-up factors cannot be estimated).

The improvements described result from a better uranium substrate and a less reactive plating solution. Using the $\mathrm{H}_{2} \mathrm{SO}_{4}-\mathrm{HCl}$ anodic etch solution rather than the $\mathrm{H}_{3} \mathrm{PO}_{4}-\mathrm{HCl}$ solution, the uranium surface receives a finer and more uniform etch and does not have the peaks and valleys. Since a nickel plate tends to be thinner over uranium surface peaks, and since the valleys are often not plated, a rough uranium surface can result in less protection to the uranium than expected from the amount of nickel plated. In addition, the nickel overvoltage is greater on uranium anodized $\mathrm{H}_{2} \mathrm{SO}_{4}-\mathrm{HCl}$ than in $\mathrm{H}_{3} \mathrm{PO}_{4}-\mathrm{HCl}$. This overvoltage may result in a better nickel nucleation and thus reduce the number of pore sites. The substitution of bromide ion for chloride in the watts plating solution currently used improved the plate. It decreases the rate of reaction between the plating solution and the uranium during the first moments of plating before a protective nickel. film is formed. There is less reaction product at the uraniumnickel interface, which is an important factor in plate porosity and integrity.

The experiments designed to improve the deposition process were not sufficiently complete to draw firm conclusions, except that conventional ac plating does not appear promising. The ultrasonic agitation experiments were limited to one frequency and a possibly low power output, which does not prove its lack of success. On this basis, a continuation in this part of the program, e.g., using ultrasonics with a lower frequency and higher power. eutpyt and high current pulse plating, would seem useful. 



\title{
UNCLASSIFIED
}

\author{
25 \\ APPENDIX A \\ $\underline{\text { POROSITY TEST }}$
}

\section{Introduction}

Many different techniques have been used for determining the porosity of electrodeposits on uranium metal. One such technique is the exposure of the plated specimen to an atmosphere that is corrosive to uranium such as water vapor, hydrogen, or oxygen. While this type of test gives an indication of porosity, quantitative evaluation is made difficult by the formation of oxides or hydrides that cause the plate to rupture. Another type of test involves anodization of the specimen in a solution containing a precipitant for uranium ions. Any hole in the plate allows oxidation of the uranium and formation of a precipitate at that spot. If the plate itself is not attacked significantly by the anodization, determination of the amount of uranium precipitate formed on the surface of the specimen can be used as a measure. of porosity. (16) The past customary method of making this determination has been to count the precipitate spots. This method is slow and tedious, however, and lacks: precision. Hence an alternate means was sought to measure the extent of uranium oxidation during the anodization.

Bas is

The nickcl-clad uranium specimen is anodized under controlled conditions and in a solution containing potassium ferrocyanide and potassium nitrate. The applied voltage, anode current density, and anodization time are chosen such that corrosion of the nickel is inconsequential, but such that a precipitate of uranyl ferrocyanide forms wherever the uranium metal is exposed. The amount of iron in the precipitate is then measured by $\mathrm{X}$-ray fluorescence (from the peak-to-background ratio of the iron $K$ a 1 ine). Since 


\section{UNCLASSIFIED,}

the iron in the precipitate is directly related to the amount of uranium dissolved during the anodization, the total pore area in the section measured can be taken as directly proportional to the quantity of iron and inversely proportional to the anodization time.

\section{Procedure}

1. The specimen is anodized for a measured time (long enough to produce a liberal amount of precipitate - generally minutes), at a current density of $32 \mathrm{~mA} / \mathrm{cm}^{2}$ and in a solution containing $15 \mathrm{~g} / 1 \mathrm{~K}_{4} \mathrm{Fe}(\mathrm{CN})_{6} \cdot 3 \mathrm{H}_{2} \mathrm{O}$ and $50 \mathrm{~g} / 1 \mathrm{KNO}_{3}$. Nickel sheet is used as the cathode, the cathode-anode distance is $33 \mathrm{~mm}$, and the solution is agitated. Following the anodization, the speciment is rinsed carefully and thoroughly in water.

2. The quantity of iron on the surface of a section of the specimen is determined by $X$-ray fluorescence.

$\underline{\text { Validity }}$

The validity of the test was determined by the extent of nickel dissolution during anodization. This was done by measuring the amount of nickel-containing ferrocyanide formed by $\mathrm{X}$-ray fluorescence and by polarization studies. The former technique showed a 30 counts/sec increase probably due to nickel dissolution compared to 300 to 3000 counts/sec because of uranium dissolution, while the latter method showed that less than $0.2 \mu$ of nickel is removed during anodization for 100 sec. To estimate the amount of nickel removed during the anodization step, polarization curves were run for nickel, uranium, and nickel plated on uranium pieces in the test solution. Figure 7 shows the behavior of a nickel anode having a surface area of $23 \mathrm{~cm}^{2}$. The decomposition potential is $+0.23 \mathrm{~V}$ and the current increases to a maximum value of $0.16 \mathrm{~A}$, after which the nicke
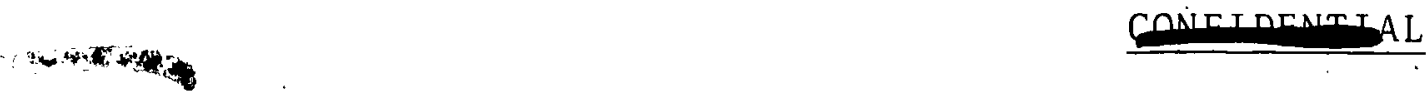


\section{UNCLASSIFIED}

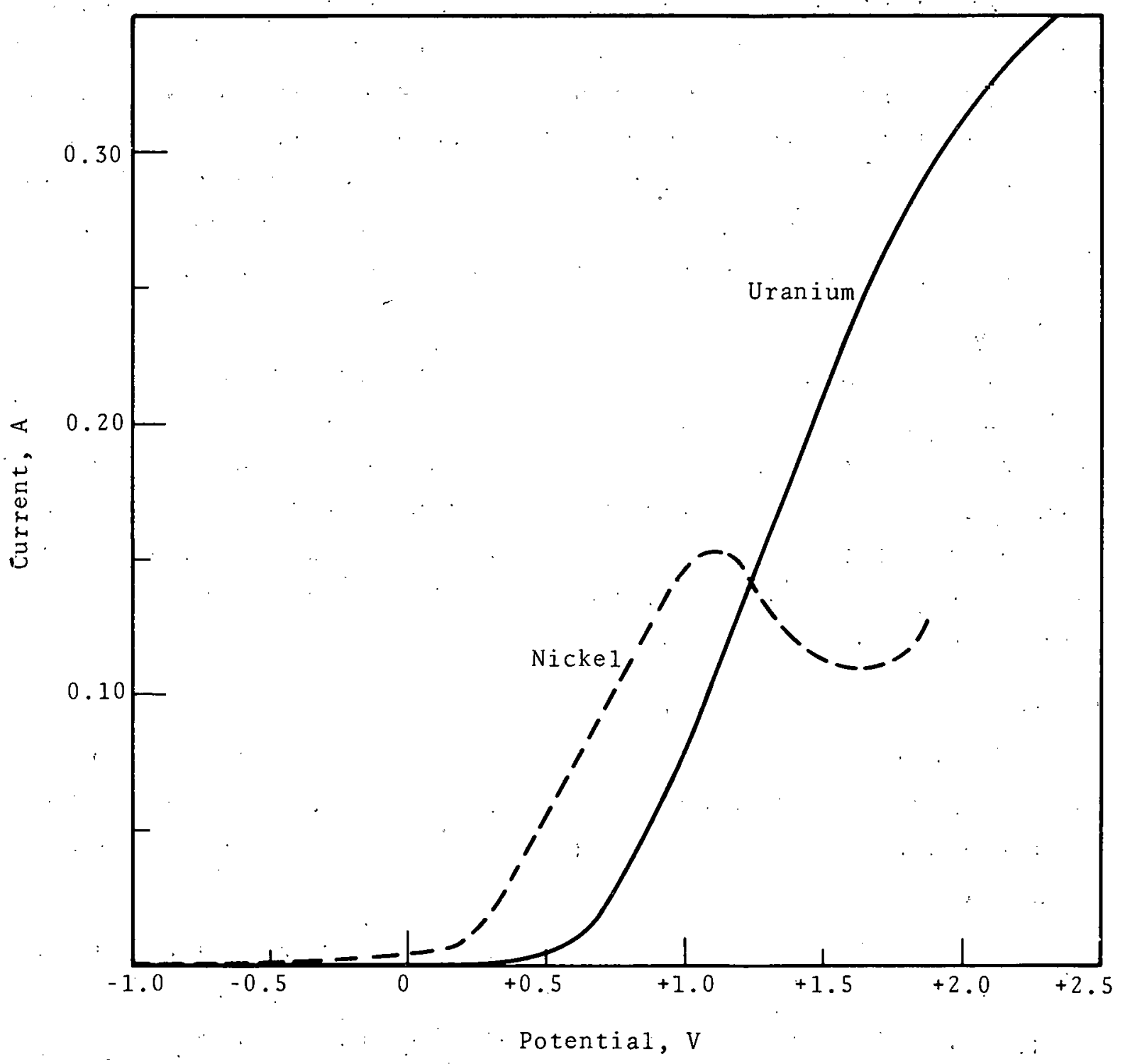

FIGURE 7

Anodic Polarization Curves of Uranium and Nickel 


\section{UNCLASSIFIED}

surface tends toward passivation and the current falls off to $0.11 \mathrm{~A}$. Figure 7 also shows the polarization curve of a uranium microelectrode that has a surface area of $\sim 1 \mathrm{~mm}$. Although the uranium decomposition potential is higher than that of nickel, the anodizing current attainable for uranium is much higher than that for nickel; thus the amount of nickel removed is limited. For a $100-\mathrm{sec}$ anodization at the limiting current of $0.11 \mathrm{~A}$, it is estimated that less than $0.2 \mu \mathrm{nickel}$ is removed (which is negligible for present studies). Figure 8 shows the curves for. a plated specimen in which the uranium precipitate was noticed at about $-2.1 \mathrm{~V}$.

Figure 9 shows polarization curves for a plated specimen that has been made cathodic to reduce the passive film and then anodized. As a result, the maximum current for nickel was very high, and large amounts of nickel ferrocyanide were formed at the anode. Then for a successful test, it is essential that a high voltage be placed across the cell to ensure the nickel plate stays relatively passive.

\section{Results}

The porosity test described above has proven to be an easily-applied technique for obtaining meaningful numbers for relative nickel plate porosities. Typical results are shown in Figure 10 .

The utility of the test procedure was. shown in a series of experiments in which relative porosities of nickel coats of different thickness, prepared by plating in identical baths but for different times, were measured. The curve relating porosity (in an arbitrary scale) with nickel thickness (Curve A) shows an exponential decrease in porosity with increasing thickness over the range studied. In another application the test indicated the formation of a less porous plate from a sulfamate bath than from a Watts bath (Curve B). Generally, it is felt that the test 


\section{UNCLASSIFIED}

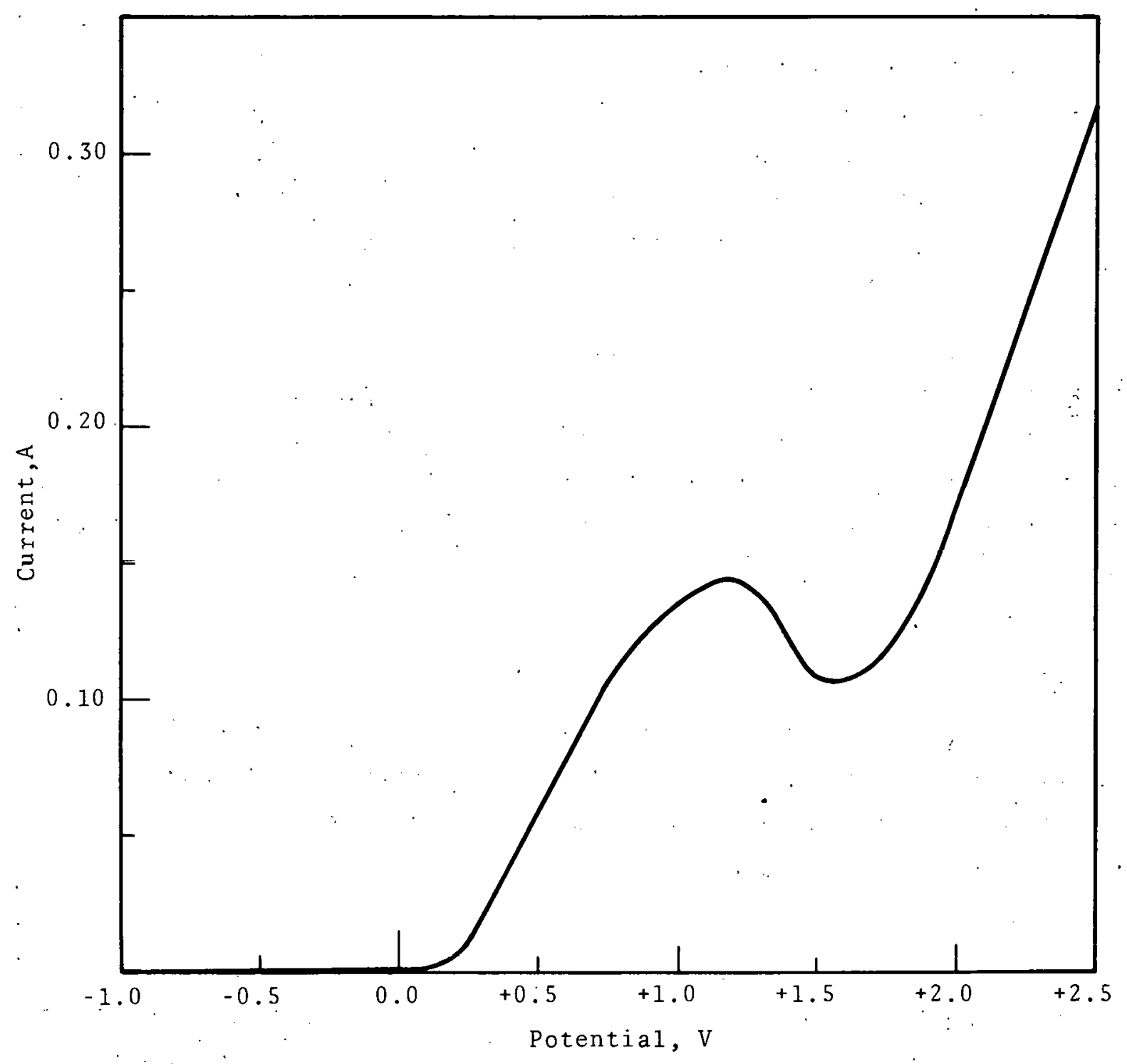

FIGURE 8

Anodic Polarization Curve of Nickel Plated Uranium 
UNCLASSIFIED.

7

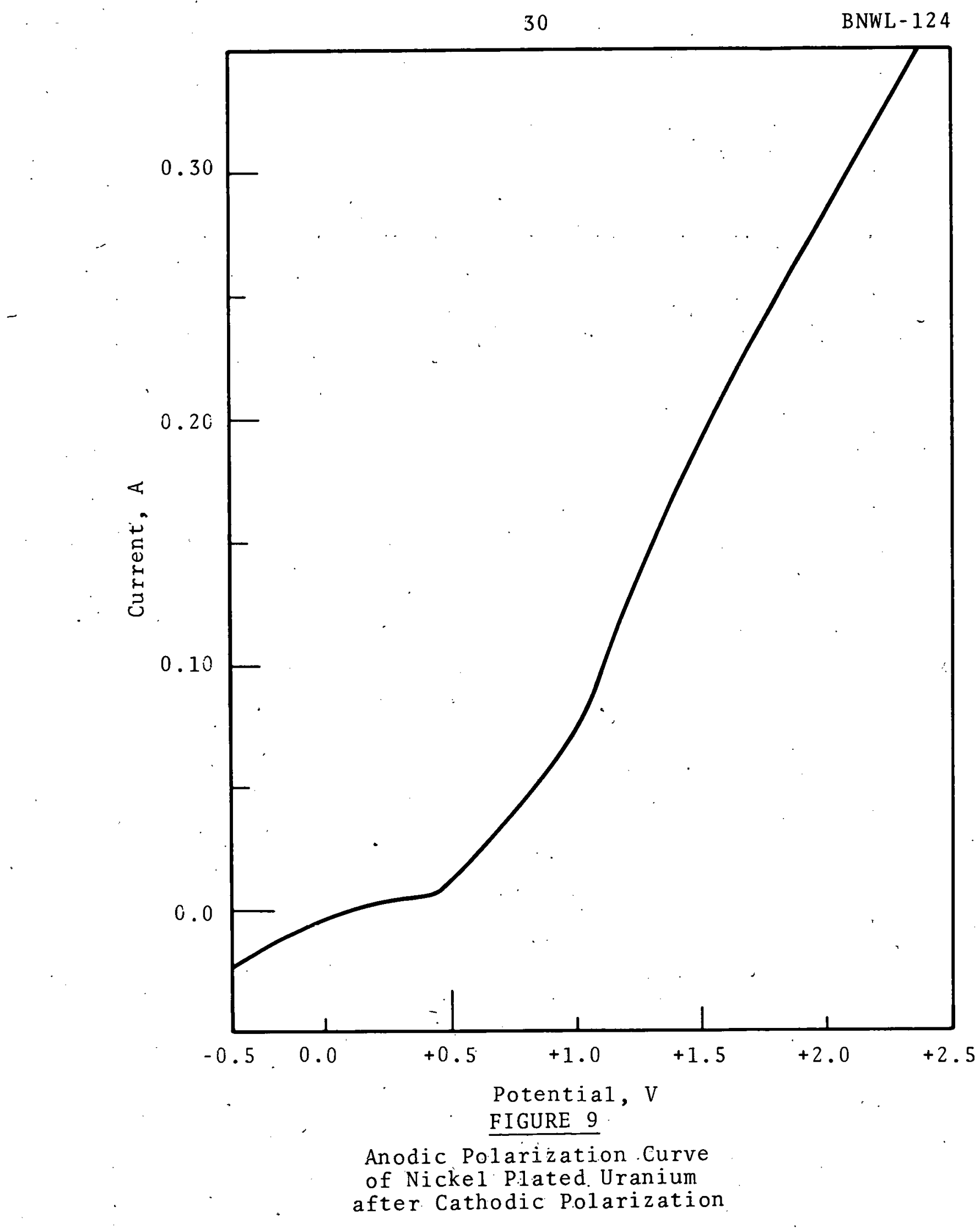

UNCLASSIFIED. 
UNCLASSIFIED

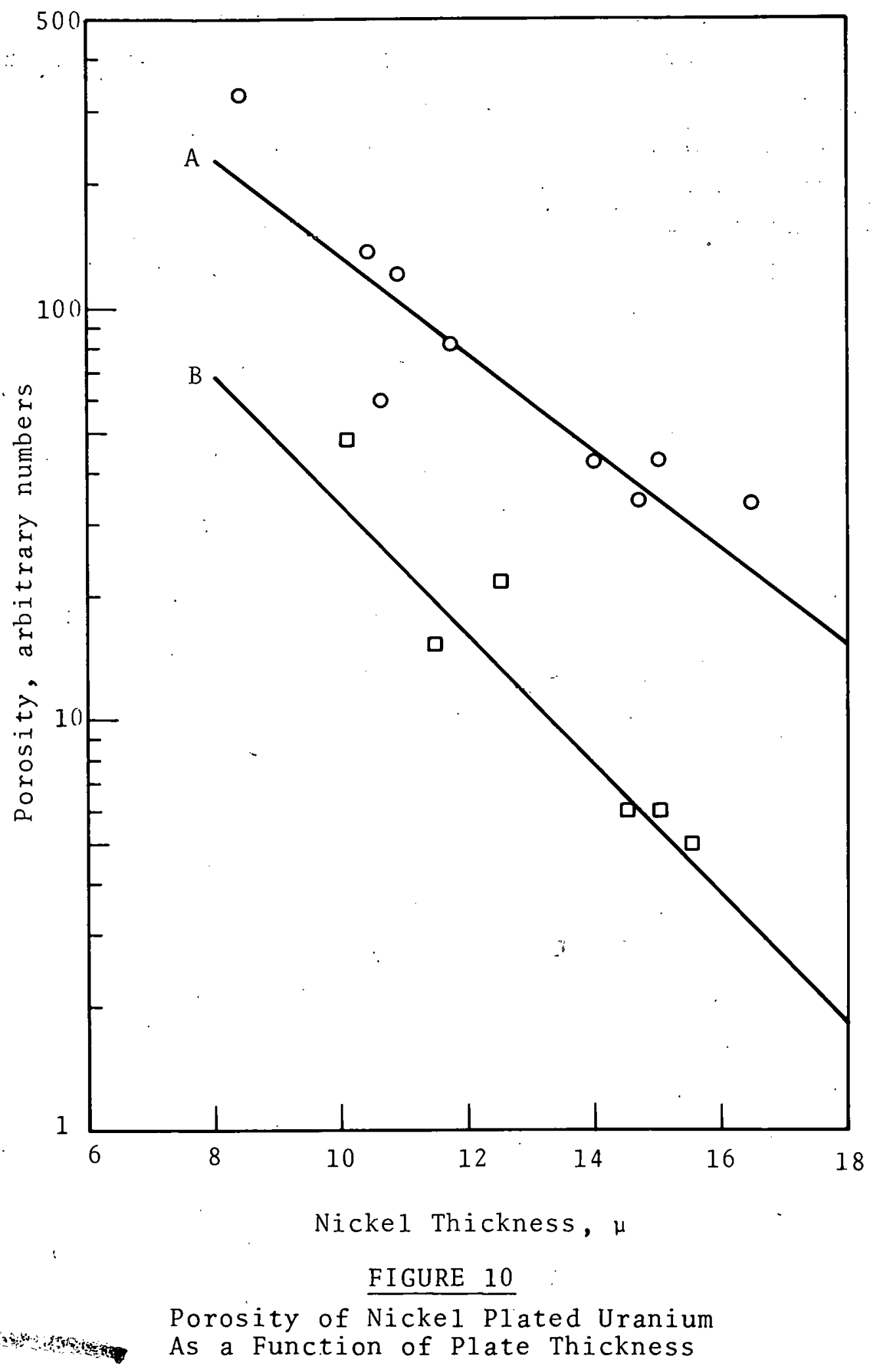




\section{UNCLASSIFIED}

can be used as a valid indication of relative porosities where the indicated difference in arbitrary porosity numbers is a factor of two or greater. This technique can be extended to other systems in which a precipitate are formed with the base metal which contains an element different from the base metal and cladding and has an atomic number greater than 12 . The cladding must not anodize at the emf necessary for the formation of the precipitate: It is possible that ceramic claddings may be tested successfully if less than 5 mils thick. 


\section{REFERENCES}

1. C. A. Strand. Interim Report on Hot Die Sizing Variables Test, HW-76858. May 20, 1963. (Secret)

.2. R. L. Braun and.R. W. Stromatt: Uranium Surface Electrochemistry and Nickel Electroplating, Interim Report, HW-79582. November 1963. (Confidentia1)

3. J. S. Riney, G. M. Schmid and Norman Hackermann. Review of Scientific Instruments, vol. 32, p 588. 1961.

4. J. K. Gore and R. Seegmiller. "Surface Treatments and Electroplated Coatings on Uranium", Plating, vol. 50, p.215. March, 1963.

5. J. G. Beach and C. L. Faust. Electroplates on Thorium and Uranium for Corrosion Protection and to Aid Joining, BMI-1537. Battelle Memorial Institute, August 14, 1961.

6. R. A. U. Huddle. U. S. Patent 2,835,630. May 20, 1958.

7. C. J. Slunder. U. S. Patent 2,872,389. February 3, 1959.

8. A. G. Gray. U. S. Patent 2,894,885. July 14, 1959.

E. W. Rebol. U. S. Patent 2,884,364. April 28, 1959.

9. A. G. Gray and W. E. Schweikker. U. S. Patent 2,836,548. May 27, 1958.

10. F. Brossa, R. Theisen, J. J. Huet, and D. Tytgat. Study of Nickel as a Diffusion Barrier Between Uranium and Aluminum, EUR-17.F. Euratom, May 1962 .

11. R. G. Post and W. B. Kerr. Semiproduction Nickel Plating of Fuel Elements, HW-35609. July 11, 1955. (Confidential).

12. C. L. Frederick and G. L. Waldkoetter. Fuel Core Tester-UT-2, HW-65701. July 1960.

13. A. T. Vagramyan and Z. A. Solov'eva". "Plating with Alternating Current", Technology of Electrodeposition. Moscow 1959. Translation by A. Behr. Robert Draper Ltd., Teddington, - Great Britain, 1961. p 95 .

14. S. M. Kochergin and G. Ya. Vyaseleva. "Structure and Properties of Nickel Electrodeposits Obtained in an. Ultrasonic Field", Russian Journal of Physical Chemistry, vol. 38, p 456. English Translation. April 1964 .

15. D. E. Couch and A. M. Brown. Coatings for Uranium, SCR-307, p 25-27. Sandia Corporation, December 1961.

16. A. T. Vagramyan and Z: A. Solov'eva. "Porosity", Technology of Electrodeposition. Moscow 1959. Translation by A. Behr. Robert Draper Ltd.; Teddington, Great Britain, 1961. p 280. 


\section{UNCLASSIF̈IËD}

ONSITE DISTRIBUTION

Copy Number

Pacific Northwest Laboratory

$\begin{array}{rr}1 & \\ 2 & \\ 3 & - \\ 13 & \\ 14 & \\ 15 & \\ 16 & \\ 17 & -\end{array}$

E. W. Christopherson

K. M. Harmon

J. R. Lundquist

A. M. Platt.

R. W. Stromatt

E. E. Voiland

M. T. Walling, Jr.

Technical Information Files

General Electric Company, Richland

22

23

24

25

26

27
G. F. Jacky

J. T. Knight

J. T. Stringer

H. F. Tew

GETA File Copy

Rich 1 and Operations Office

OFFGITL DISTRIBUTION

No. of Copies

1

2

1

2

1

2

1

2

2

1

1

1

2

2

1

1

1

1

1

1

4 .

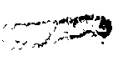

ACF Industries, Inc.

Aerojet-General Corporation (NASA)

Aerojet-General Corporation, Sacramento

Aerojet-General Nucleonics

Aerojet-General Nucleonics (NASA)

Aeronautical. Systems Division

Air Force Electronic Systems Division

Air Force Weapons Laboratory

Airesearch Manufacturing Company, Phoenix

Albuquerque Operations Office

Allegany Ballistics Laboratory

Allis-Chalmers Manufacturing Company

Allis on Division-GMC

Argonne National Laboratory

Army Ballistic Research Laboratories

Army Materials Research Agency

Army Nuclear Defense Laboratory

Army Picatinny Arsenal

Army Weapons Command

AEC Patent Office

Atomic Energy Commission, Washington 


\section{UNCLASSIFIED}

OFFSITE DISTRIBUTION (Contd.)

No. of Copies

2

1

1

1

1

2

1

1

2

1

1

2

1

1
Atomic Power Development Associates, Inc. Atomics International Battelle Memorial Institute Bendix Corporation (AF) Brookhaven National Laboratory Bureau of Mines, Albany Bureau of Naval Weapons Bureau of Ships Carolinas-Virginia Nuclear Power Associates, Inc.

Central Inteligence Agency Chicago Patent Group Combustion Engineering, Inc. Combustion Engineering, Inc. (NRD) Division of International Affairs, Brusse1s

Dow Chemical Company, Rocky Flats

du Pont Company, Aiken

du Pont Company, Wilmington

Edgerton, Germeshausen and Grier, Inc., Goleta

Edgerton, Germeshausen and Grier, Inc., Las Vegas

General Atomic Division.

General Dynamics/Astronautics (AF)

General Dynamics/Astronautics (NASA)

General Dynamics/Electric Boat Division

General Dynamics/Fort Worth

General Electric Company, Cincinnati.

General Electric Company (FPD)

General Electric Company (MSVD)

General Electric Company, San Jose

Goodyear Aerospace Corporation

Goodyear Atomic Corporation

IIT Research Institute

Institute for Defense Analyses

Ion Physics Corporation

Iowa State University

Jet Propulsion Laboratory

Johns Hopkins University (APL)

Knolis Atomic Power Laboratory

Ling Temco Vought, Inc.

Lockheed-Georgia Company

Lockheed Missjles and Space-Company (BUWEPS)

Lockheed Missiles and Space Company (NASA)

Los Alamos Scientific Laboratory 


\section{UNCLASSIFIED.}

BNWL-124

\section{OFFSITE DISTRIBUTION (Contd.)}

No. of Copies

1

1

1

1

1

1

1

1

1

2

4.

1

1

1

1

1

1

1

1

1

1

1

1

1

1

1

1

1

1

1

1

1

1

1

1

1

.1

2

5
Mallinckrodt Chemical Works.

Marquardt Corporation

Materials Advisory Board

Metals and Controls, Inc.

Mound Laboratory

MSA Research Corporation (C00-765)

NASA Ames Research Center

NASA Langley Research Center

NASA Lewis Research Center

NASA Manned Spacecraft Center

NASA Marshall Space F1ight Center

NASA Scientific and Technical Information

Facility

National Aeronautics and Space

Administration, Washington

National Lead Company of Ohio

National Reactor Testing Station (PPCO)

Naval Ordnance Laboratory

Naval Radiological Defense Laboratory

Naval Research Laboratory

Naval Weapons Evaluation Facility

Naval Weapons Laboratory

Navy Marine Engineering Laboratory

New Brunswick Area Office

New York Operations Office

Nuclear Materials and Equipment Corporation

Nuclear Metals, Inc.

Oak Ridge Operations office

Office of Naval Research

Office of the Chief of Naval Operations

Pratt and Whitney Aircraft Division (NASA)

Public Health Service

Rand Corporation

Reactive Metals, Inc., Ashtabula

Republic Aviation Corporation

Richland Operations office

Sandia Corporation

Sandia Corporation, Livermore

San Francisco Operations Office

Savannah River Operations Office

Sylvania Electric Products Inc.

Tennessee Valley Authority

Tracerlab, Richmond

TRW Space Technology Laboratories

Union Carbide Corporation (ORGDP)

Union Carbide Corporation (ORNL) 


\section{UNCLASSIFIED}

\section{OFFSITE DISTRIBUTION (Contd.)}

No. of Copies

Union Carbide Corporation (Paducah Plant) Union Carbide Corporation ( $Y-12$ Plant) United Nuclear Corporation (NDA) University of California, Berkeley University of Cali fornia, Livormere Walter Reed Army Medical Center Westinghouse Bettis Atomic Power Laboratory Westinghouse Electric Corporation Westinghouse Electric Corporation, Lima Westinghouse Electric Corporation, Lima (AF) Westinghouse Electric Corporation, (NASA) White Sands Missile Range Division of Technical Information Extension 